\title{
MASILI
}

\section{SEISMIC ANALYSIS OF THE NUCLEAR FUEL SERVICE REPROCESSING PLANT AT WEST VALLEY, N. Y.}

R: C. Murraỳ

T. A. Helson

A. H. Davito.

Fing 24,1977

Work performed under the auspices of the U.S. Depertment of Energy by the UCLLL under contract number W-7405-ENG-48.
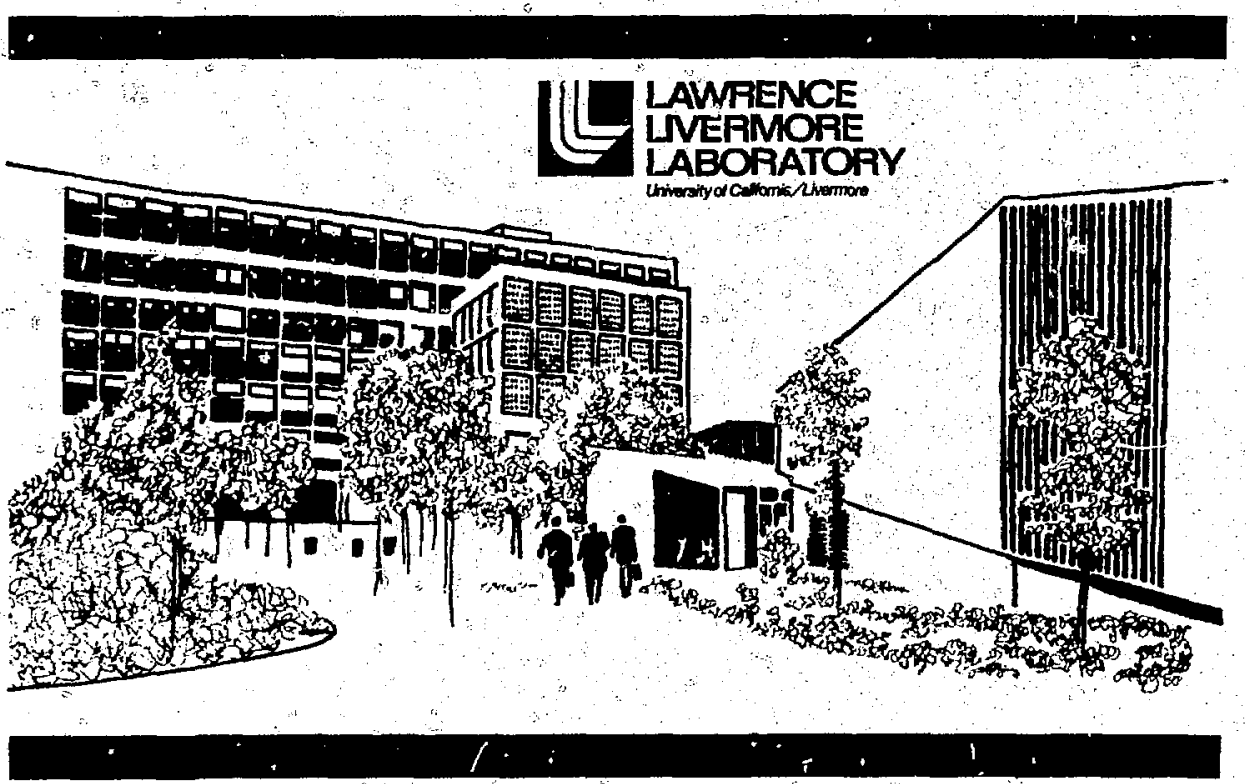

. 
"The report wis prepered w a cécount or work uponeored by the Uailed Statwe Gommmot. Notther the Undtid sium nor the Unitod Strite Dopartiment of Energy, nor any of thedr em. ployem, ace an of thele contractores abcon-

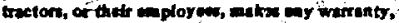
expres or taptiod, or ciomes ay hol liebilty or rempondiblity for the sceuracy, complotenien or mefuines of any information, epparatus. product of procen diecloed, or repreants that Ite une would not intringe prlvately-owned ridhit."

\section{NOTtCE}

Referetce tc a company or product name does not imply approval or recommendation of the product by the University of California or the U.S. Depurtinent of Energy to the exclusion of others that may be suituble.

Prhited In the United Statel of Americi Availubls from

National Techoical Informstion Service U.S. Depertment of Commeres 5285 Port Royd Road Springiteid, VA 22161

Prise: Printed Copy \$ : Mtcroflche $\$ 3.00$

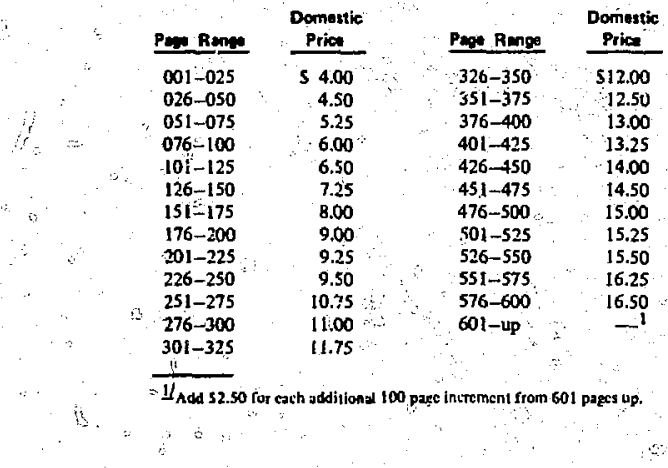

$$
{ }^{\infty}
$$




\title{
LAWRENCE LNERMORE LABORATORY
}

\author{
inversity of Caltornia/Linermore, Calitomia/ 94550 .
}

\section{UCRL-52266 \\ SEISMIC ANALYSIS OF THE NUCLEAR FUEL SERVICE REPROCESSING PLANT AT WEST VALLEY, N. Y.}

\author{
R. C. Murray \\ T. A. Nelson \\ A. M. Davito
}

MS. date: May 24, 1977

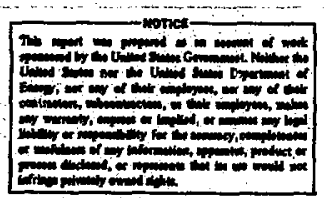




\section{Contents}

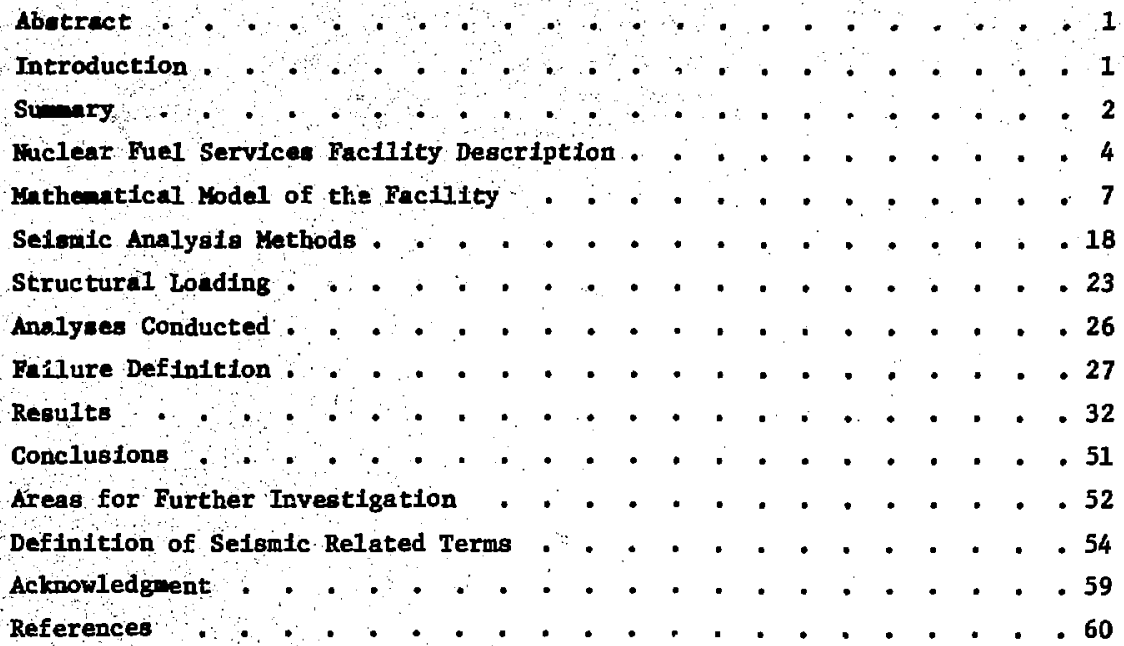




\section{Seimmic Analysis of the Nuclear Fuel Service Reprocessing Plant At West Valley, N.Y.}

\section{Abstract}

This report vee prepared at the request of the Nuclesr Regilatory Comisglon as part of a license review of the nuc'ear fuel reprocessing plant opercted by Nuclear Fuel Services, Inc., at We'st Valley, N,Y. The report discusses the approach used by the Lawrence Livermore
Laboratory in performing an Independent selsmic analysis of the factlity It Includes a description of the facflity, our modeling and anslysis techniques, falluce criteria, results, and conclusions. Two modes of failure are identified and their consequences discussed.

\section{Introduction}

Nuclear Fuel Services, Inc., (NFS) began operations in 1966, at its nuclear fuel reprocessing facility located at West Valley, New York. This plant was the first commerclal facllity to separate reusable uranfum and fuel-grade plutonium from reactor spent fuel. As the number of reactors increased around the country, so did the demand, for recycling spent fuel. Thus, NFS decided to undertake a modification and expansion program at Its West Valley factlity which would Increase capactty by $150 \%$. This would also involve the approval of the Nuclear Regulatory Commisaton (NRC) to obtain a license for reprocessing. As part of the NRC's license revien, the Lawrence Livermore Labora- tory (LLL) was asked to provide a realistic independent selsmic analysis of the facility after modIfication. LLI was to identify the level of ground motion (up to $0.2 \mathrm{~g}$ ) that the plant could withstand before faflure begins and also to identify any weak areas in the plant from a structural viewpoint. To accomplish these tasks; we took the following approach:

- Became familfar with structure

- Reviewed SAR

- Selected analysis technIque .....

- Reviewed, selectedi and implemented structural modeling: techniques

- Selected structural loading 
- Performed arialyses

- Developed fallure criterla

- Interpreted results

- Dren conclusions

The Los Alamos Sctentific Laboratory (LASL) was also asked by NRC to conduct an Independent selsmic analy. Is, LLL and LASL conducted independent investigations but were allowed to exchange Information. : The results of these studies will be used by the NRC to assess the consequences of structural fallure.

Throughout the profect we used our judgment extensively to make modeling deciofons and to select workable failure criteria. We relied on past experfence, published 1iterature, and discussions with the NRC, NFS, LASL, and DRAVO (architect/engineer firm selected by NFS for the plant modification) to asilat in making these dectioions.

\section{Summary}

Summarized below is the approach taken and the results obtained from our analysis of the NFS facility.

\section{STRDCTURAL FANTIIARIZATION}

We gained an understanding of the structure by site visits to the Hest valley facility, a review of the structural drawings supplied by NFS, and the construction of a plastic scale mode1. ThIs model allowed us to study the Interrelation of various structural compcnents and tu see how they were interconnected, The plastic $-\quad$ model served as a very useful ald in constructing the computer model of the facility.

\section{REVIEW OF SAFETY ANALYSIS REPORT}

A review of the Safety Analyais Report (SAR) for the NFS modification allowed is to become familier with the Weat Valley site, soll conditions, and foundation. The structure has a pile foundation consisting of approximately 500 H-P1les from 30- to 60-ft long. We used this document as a source of information for our foundation modeling.

The SAR also provided us information to assist in selecting the structures to be included in our analysis.

SELECTION OF ANALYSIS TECENIQUE

We reviewed available static and dynamic methods of analysis used to 
estinate the selonic response of structures and they are discussed and compared We elected to conduct a static analysis to estlmate the dead load response. Our aelomic analyaes were conducted by using the response spectrum approach:

REVIEW OF STRUCTURAL MODEL TECHNIQUE

We revilewed the literature and discussed modeling philosophy with NRC and DRAVO before adopting a modeling plan. Our model had to represent the mass and stiffness distribution of the facility as well as account for the File foundation and embedded structures interacting with the surrounding soil. To account for the expected varlations in foundation behavior, four foundation models were analyzed. The scheme we selected was to use uncoupled linear springs to model the foundation interaction and to use a three-dimensional finite element assemblage of plate and membrane elements to model the structure. Additional mass was added to represent heavy equipment loads and parts of the structure not included as finite elemente.

SELECTION OF STRDCTURAI LOADING

Since site-specific spectra were not avallable at the West Valley ofte, we used the spectra presented in
Regulatory Guide 1.60 to represent the frequency content of the free field Input ground motiok. We also chose a damping value of $7 \%$ for ali parts of the model.

Th1s spectrum was used as input to the structure for the dynamic analysis. The spectrum was applied at the foundatton level, and all foundation points were subjected to the same inpts..

\section{PERFORMANCE OF ANALYSIS}

We conducted linear elastic analyses by both static and, response spectrum techniques to estimate the structural behavior during an earthquake. Static dead-load results were combined with results from the four response spectrum analyses to estimate the onset of faflure. The static dead-load analysis was also useful for verifying our model.

\section{DEVELOPMENT OF FAILURE GRITERIA}

Failure criteria were needed for both piles and shear walls. We developed these criteria from a literature review and discussions with NRC. These criterfa were then. used to determine the level of ground motion at which individual components of the model would fatl. Our analyses allowed us to estimate the onset of failure. A progresstve fallure assessment was not possible slnce a linear analysis technique was selected: 
- Concrete block wa11s of 1 ess critical structures beg in to

Results from the anslyses were assembled and studied Review of this data allowed us to draw the following conclustons. These values are based on worst case estimates from the foundation cases we studied:

Reinforced concrete shear walls of the confinement cel1 structures begin to faij. in the range of 0.09 to $0.15 \mathrm{~g}$. fail in the range of 0.03 to $0.07 \mathrm{~g}$.

- Iateral pile fajlures began at 0.118 .

- Pile tenaion fallureo began at $0.17 \mathrm{~g}$.

Spectific locations and discussions of the onset of fallures can be found in the Results and Crnclusions sections.

\section{Nuclear Fuel Services Facility Description}

The Nuclear Fuel Service Reprocessing Plant is located south of Buffalo, New York, on the western New York Nuclear Service Center stte near West valley. A site plan of the NFS facilIty ${ }^{1}$ is shown in UCID-17453. * In this study, we concentrated on the process building ( $\mathrm{Fig}$. 1) which is constructed of concrete block and reinforced concrete, and is approximately $250-\mathrm{ft}$ wide by 200-ft long by 85-ft high (Ffg 2). The main reprocessing. operations are performed inside the process bullding and Inĉlude shearing the fuel, separating reusable ieterials, and handling the waste neterials. Although the existing

\footnotetext{
A companton report contating
} aupporting documentntion. process building has a stack mount d on it, both NFS and DRAVO indicated that the stack would be relocated during modifications to the plant; therefore, it was not included in our analysis. However, the equipment that would be in the plant after modification was included.

The bufldings adjacent to the process building were not included in this analysis directly. A review of the Fuel Receiving Station, Utility Butlding, Manipulator Service Module Repair Shop, and Iodine and Acid Recovery Cell suggested that these etructures could be separated from the process building. The process bullding offices were included in our analysis only indirectly; we included the weIght of the conçete block construction material. 


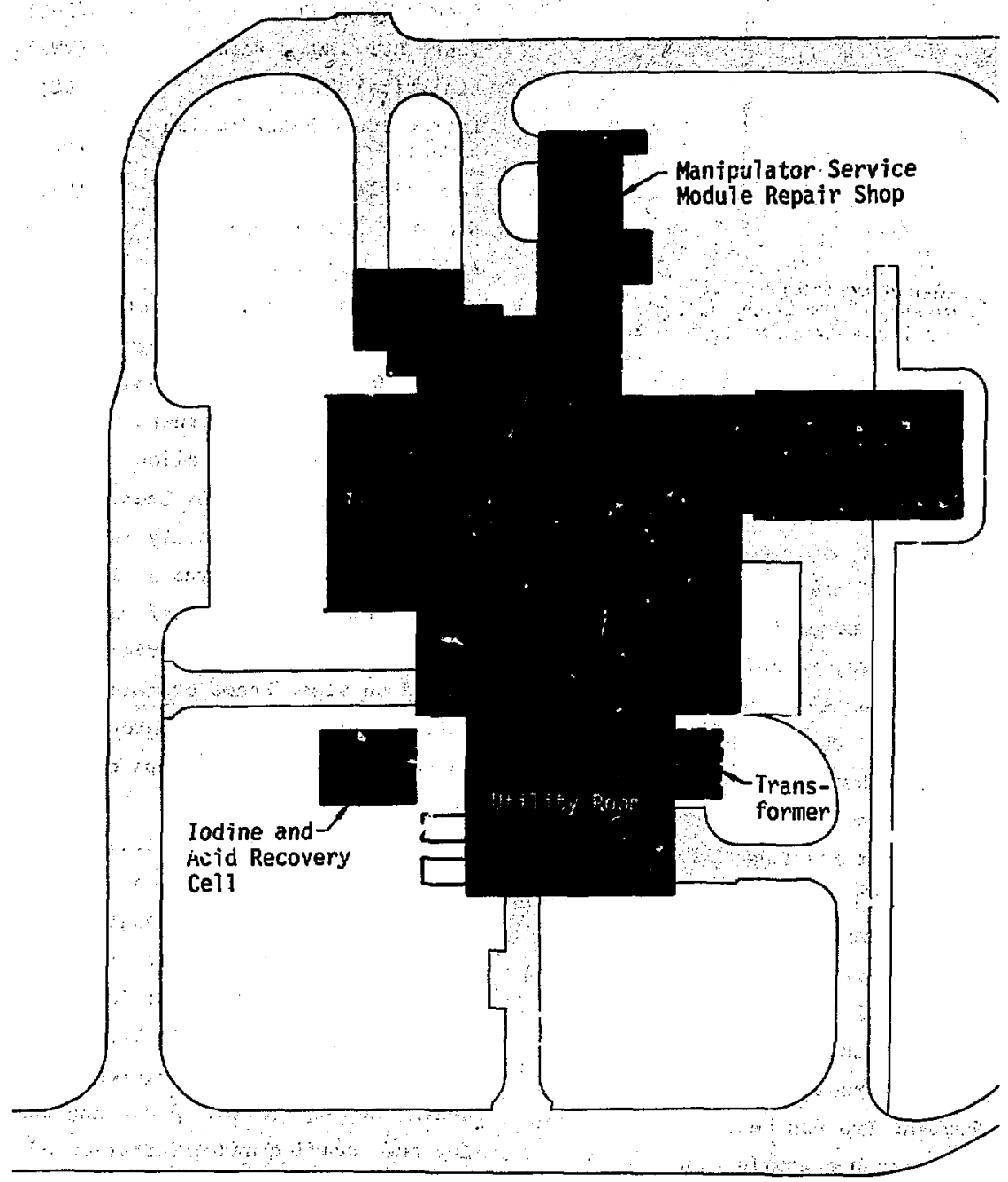

Fig. 1. MFS prosess building and adjacent structures. 


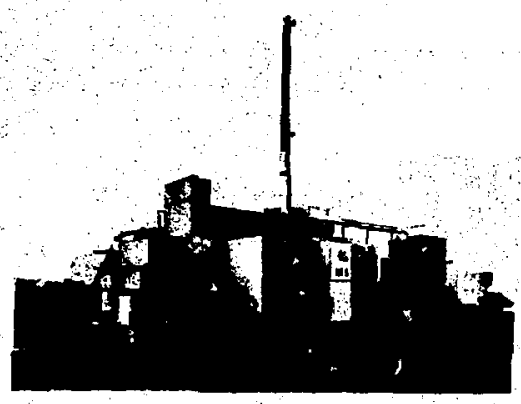

F1g. 2. Fxiating NFS factlity before nodiflcation (looking east).

The process building is a very complex structure composed of many Individual cells, These cells are of refnforced concrete constriction with their floors, walls, and cellings rang.tng fron 1 - to $6-f t$, thi k: The location of these major cells relative to each other was determined from refrucessing requirements, rather than structural behavior. This cell arrangement 1 s one of this main reasons for the complexity of the facility. The names of the major cells included In our analygia are listed below:

Process : Mechanical Cell

General Purpose Cell

Chemtcal Process Cell

Equipment Decontamination Room
L1quid Haste Cell

Ventilation Wash Room

Analytical Cells

Extraction \& Purification Ce11s

Warm Alsie

Uranium Product Ceil

Ac1d Recovery Off-Ges Cell

(AOC)

These cells are intercomnected to each other to form an Integral structure. Some of the interconnections are monolothic while others provide vertical supports and allow relative lateral motion on steel bearlng, plates. Surrounding the heavily reinforced concrete cell structures is 11ghter construction consisting of masonry walls and metal deck flooring supported on steel beams or masonry walls. This construction houses the control room and other less eritical parts of the structure.

The massive cell structure is supported by a pile foundation. This was required due to the inadequate bearIng capacity of the surface layers of the soil at the site. The foundation consists of approximately 500 H-bearIng piles located in staggered rows under the cell walls. A drawing showing the location and orientation of (EDR) the piles to given in UCID-17453. 


\section{Mathematical Model of the Facility}

STRUCTURAL MODELING TECHNIQUES

Several modeling techniques can be used for the selsmin analyses of complex facilities such as NFS. Key aspects of these techniques are summarized below, and the modeling approach we selected is indicated.

After becoming familiar with the geometry and construction of a structure, a mathematical model may be constructed. The analyst should constder the anticipated loading description and analysis technique. The model must incorporate all the important response characteristics of the actual structural system belng analyzed (e.g., mass and stiffness distributions, damping; and pertinent effects of soll-structure interaction). The mathematical model const-ucted $1_{B}$ usually too complex to utilize a closed-form solution so approximate methodis must be enployed. Either of two methods can be used to "discretize" the structure: the concentrated massspring (1umped-mass) approach or the finite element approach.

The concentrated mass-spring approach divides the structural system Into discrete mass points connected by massless springs that represent the stiffness characteristics of the structure. These springs may represent truss members, beams, or shear paneis. An example of a simple lumped-mass model is shown in Fig. 3 . In this model, the actual mass is

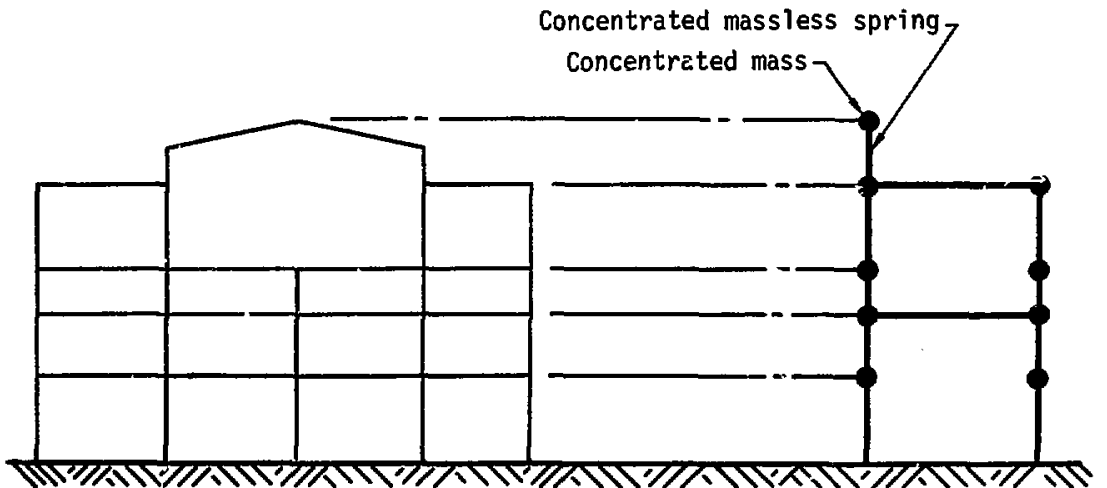

Actual structure

Concentrated mass-spring model

Earthquake motion

F1g. 3. Concentrated mass-spring representation of a structural system. 
concentrated at the approprlate level and the stifnecs of the structure $1 s$ iodeled with boar elenterts that reflect both the bending and shear stiffneas of the rast structur

The finite element approach is a technique for "dlecretizing" a atructure Into an assemblage of elements. Each element models the mass and stiffness distribution of part of the atructure, The mathematical model constructed may be composed of dffferent types of elements to represent differences in atructural behavior. Elements are currently avallable to odel truss, beam, shear wall, plate, she11, and plpe behavior. The use of the finite element procedure elfminates the need to approximate continuous structures by concentrated massspring systems.: Figure 4 shows a finite element representation of a building whlch uses truss, beam, membrane, and plate elements to model a atructure.

STRUCTURAL IDEALIZATION OF TIE NFS EACILITI

We selected the finite element nethod to Idealize the NFs facility. This allowed us to preserve the actual gecotry and wees and stiffiess dstribution of the structure Thus, $1 t$ elfintnated the need to approximate the mase and otiffness properties by concentrating them in Individual
Plate elements to model floor and roof slabs

Beam or truss elements to mode1: structural steel bracing Membrane elements 7 to model shear resistance of structure

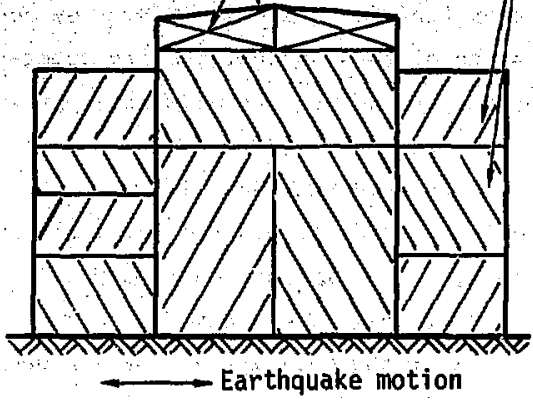

Fig. 4. Finite element model of a structural system.

members and attempting to interconnect these parts properly to form an equivalent system. The resulting finite element mesh for the NFS process buflding is shown in Fig. 5. Detalled modeling informetion is presented in UCID-17453.

The NFS Process Building is composed of cells for chemical processes constructed of relnforced concrete as well as office spaces utilizing concrete block construction: The primary consideration for this analysis is the tutegryty of the portions of the bullding conflining radloactive matertal. For this structure, thcse portions also comprise the primary latera1-force reststing system where 


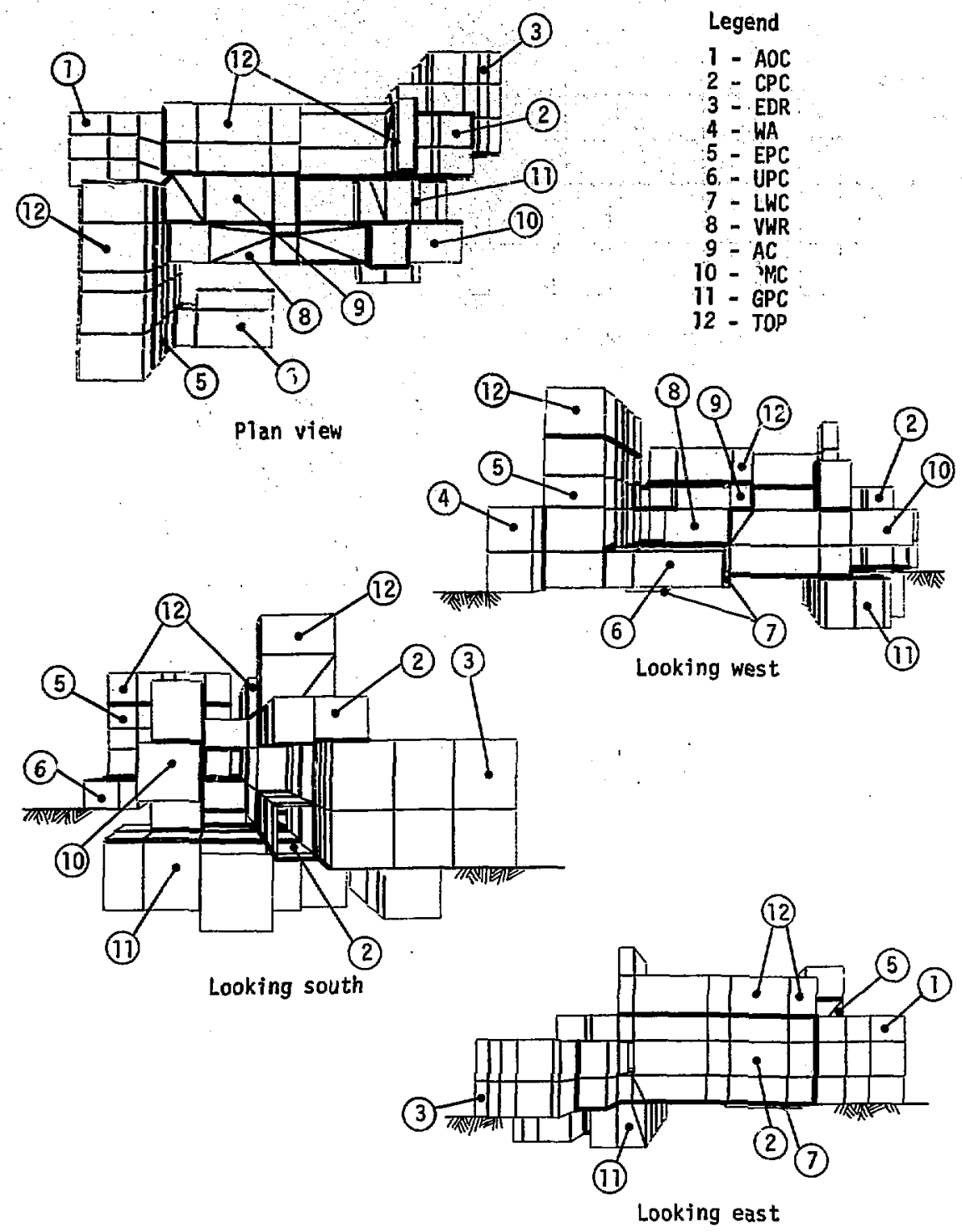

Fig. 5. Views of the mathematical model of the NFS process building showing substructures. 

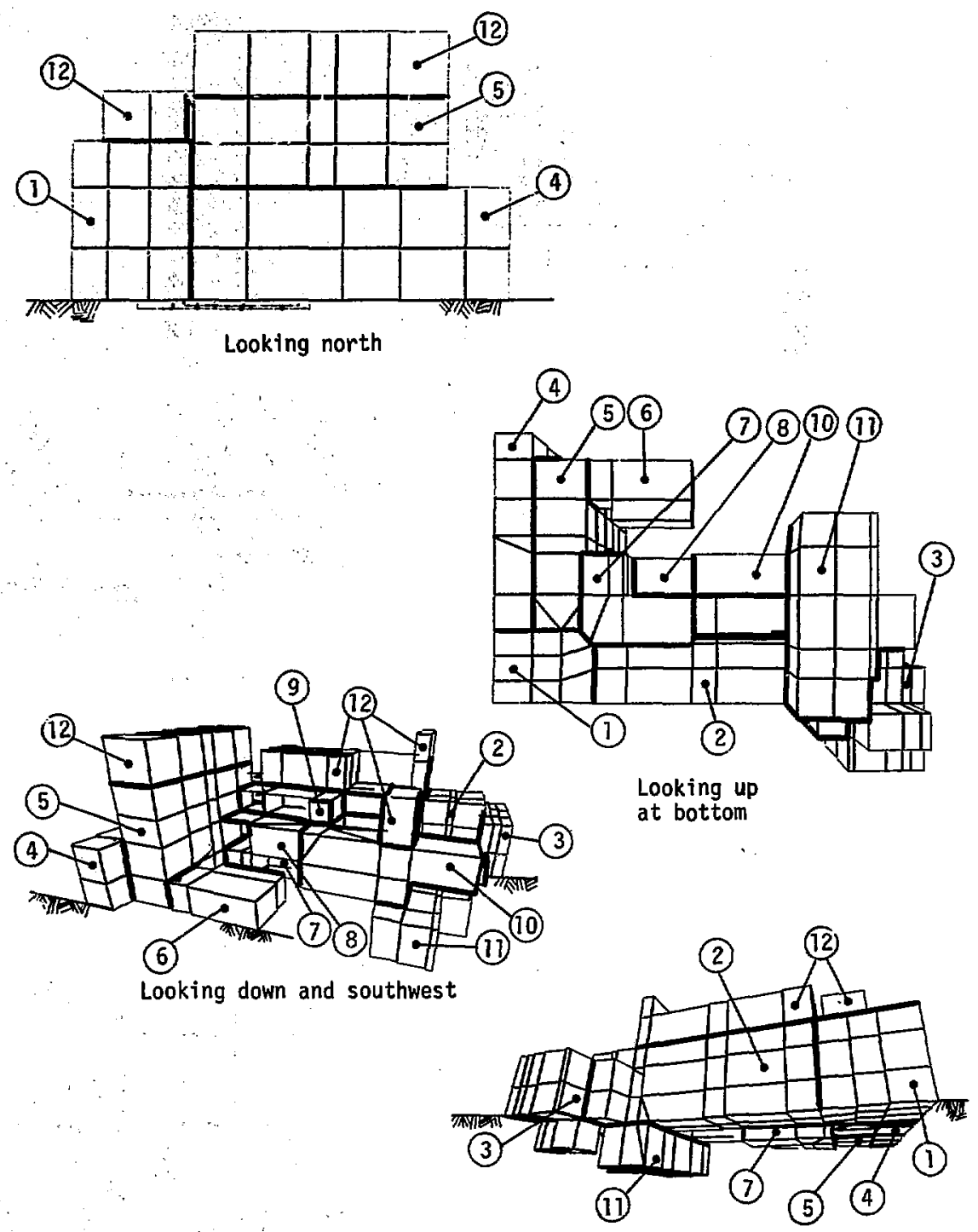

Looking up and northeast

Fig. 5. (continued): Views of the mathematical model of the NFS process building showing substructures. 
the thick shielding and confinement walls act as shear walls. The roof and floor slabs also provide confinement and are subjected to both vertical (out-of-plane) and lateral (Inplane) loads during seismic activity. Thus, the shear walls are subjected to In-plane forces while the roof and floor slabs experfence both in- and out-of-plane forces.

As discussed earlier, the process building is a complex structure which could result in a model so complex that it would tax the cupacity of the computer hardware and software used for a seismic analysis. Therefore, it was decided to use the most efficient analytical model possible to idealize the important components of the structure while still capturing the overall response characteristics of the total structure. Many essumptions and slight modifications to the actual geometry were made to develop our finfte element structural model. We excluded parapets and penetrations through walls and floors, and the 10cations of some walls and floors were moved slightly to simplify the model. This approach resulted in a threedimensional assemblage of twodimenstonal elements. Since the structure is unsymmetrical, a 3dimensional model was necessary for capturing such effects as torsional response and coupled modes. Because of the complexity of this structure, a plastic model was constructed to help visualize the relative position and interconnections of the various components. This model proved to be extremely valuable during the mathematical modeling phose of the analysis. It ts fllustrated in Fig. 6 .

The first step in formulating the structural idealization was to model the substructures (delineated by bold lines in Fig. 5). Plane stress membrane elements were used to model the shear walls. These are more efficient than thin plate elements and adequately provide for in-plane shear resistance. The roof and floor slabs were modeled with thin plate elements which contribute in- and out-of-plane mass and stiffness properties. After constructing the models, a freevibration dynamic analysis was performed on each discrete substructure, which allowed verification of the model in manageable size units. In addition,

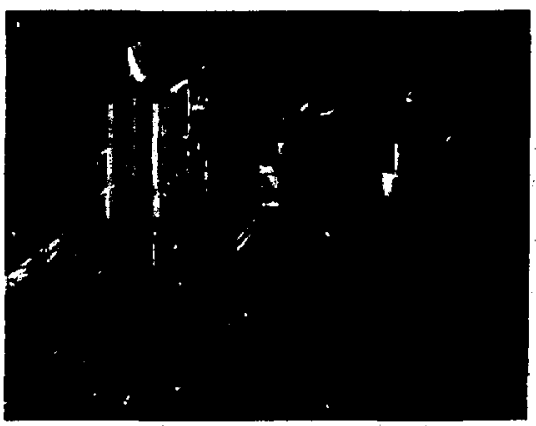

Fig. 6. Plastic model of Process Bullding (with FRS). 
the modeling of discrete substructures permitted the units to be interconnected in different ways if require. In our model, we assumed the varlous cells were rigidiy interconnected while In reality some flexibility between cells does extst. The model. constructed by LASL atcempted to Idealize flexible connections. Because of the reportedly smali relative deflections between substructures in the IASL model, it was decided ${ }^{2}$ that ILL would conduct Its entire Beries of selsmlc analyses with the rigid. connections: As a result of the freevibration analyses, it was discovered that the vertical vibration of the roof and floor slabs were dominating the lower modes. These were not considered significant to the overall response and, therefore, were eliminated by artificlally increasing the modulus of these elements. This made them respond essentially as rigid floor diapinragms which is a common assumption In conventional bullding. anilys1s.

The next step was to Include the effects of portions of the structure other than the primaxy lateral-force reslsting system. The office portions of the otructure were constructed of meterlals considerably lighter and weiker than the process cella and, thili, were deeined to have no effect on the structural incegrity of the confinement atructure. Additional mass was added to the locations (nodal points) where sigrificant portions of the bullding were omitted and where heavy equipment masses were located. Nuch of the supported equipment mass was modeled as Incredsed mass denstty of the floors and wa1ls. We also included the effects of adjacent structures in our model by adding concentrated masses at approprlate nodal points: Additional structural loasIng caused by liquid sloshtng in tanks was not Included.

In summary, the structural ldealization of the process butlding attempted to preserve:

- Mass distribution.

- Major latera1-force resisting system.

- Th- se-dfmenstonal response.

A Inear description of the structural elements and connectivity was selected to allow a response spectrum seismic analysis. Thls had the following benefits:

- It provided an estimate of response within a reasonable tIme span.

- It allowed for interpretation and verification of results based on past experience.

- It provided the only practical analysis avallable for a structure this complex.

We belleve our representation of the actual structure uses the most 
realietic approacheo currently avallable and should do well in estimating the overall motion of the structure.

FOUNDATION MODELING FOR SEISMIC ANALYSIS

All structures derive support from i Foundation through whtsh any earth1. r.ta motions w111 be transmitted. n the past, seismic analyses were performed by uaing a noninteractive system that assumed the foundation was rigid. Since that. time, many authors have Indicated that the compliance of a foundation can have a significant effect on the seismic rasponse of a structure (see Ref. 3).

Two approaches may be used to model soil-structure interaction. A fully interactive approach attempts to account for feedback of the structural response to the soll medium as well as accounting for foundation compliance. This technique usually employs a nonlinear finite element characterization of the complete soilstructure system. Between the two extremes of noninteractive and fully interactive approaches is an approach which accounts for foundation compliance but utilizes a given free-field surface motion as an input forcing function. Using this approach, the fixity of the foundation to the soll medium can be determined independently from the loading conditions. A 1inear foundation stiffness becomes a structural attribute and, as such, will be reflected in the natural frequencles and mode shapes of the structure. The methods employing this approach are frequently referred to as half-space methods and are applied to nonpile foundations as in Ref. 4, and to pile foundations as in Ref. 3. Some IInitations of each method are summarized In Table 1.

It was concluded ${ }^{3}$ that, in comparison with finite element methods, halfspace methods offer two major advantages. First, they capture the 3-dimensional response of the structure and, second, they are economical. Therefore, the approach employing halfspace methods was utilfzed for the NFS facility. The resulting linear system is consistent with the response spectrum method of analysis chosen for the structure.

SOIL CONDITIONS AT THE NFS SITE

The process building is located on soil of glacial origin with the depth to bedrock varying from 70 to $110 \mathrm{ft}$. The pertinent soll properties for pile stiffness determination are those of the surface region for lateral stiffness and the regions near the pile tip for vertical stiffness. The soil data were supplied by Dames \& Moore via Supplement 17 to the S.A.R. ${ }^{1}$ which consisted of standard penetration 
Table 1. Limitations of the half-space and finite element methods.

Half-Space method:

Does not include materlal and radtation damping.

- Cannot model multilayer soil. deposits easily.

Neglects structure - structure Interaction.

- Guidellnes are presently scarce for determining dynamic spring stiffnesses.
Finite element method:

- Appropriate three-dimensional codes are not available. Preßantly requires a plane strain solution.

- High-frequency information may be lost because of mesh alze or the use of Rayleigh damping.

- The extent of the model may not be sufficlent to eliminate wave reflections from boundarles.

- Analysis is more complex and expensive than for the half-space method.

a Radiation damping accounts for the energy lost by radiation of waves from the base of the structure.

reslotance from.field tests correlated with relative density, using the Glbbs and Holtz relationship.

The aurface material consists of a 15- to 25-ft. layer of medium dense to dense predominantly cohestonless soll. Therefore, the modulus is assumed to increase linearly with depth. The relative density varied from 55 to 95\%, from which the coefficient of modulus variation, "f", was determined to be 25-55 tons/ft ${ }^{3}$ (Ref. 5). These cömprise the limiting soil values for which the Iateral-pile stiffnesses were computed....;

The piles terminate approximately $60 \mathrm{ft}$. below. grade and rest elther In stiff silty clay or very dense fine-to-coarse gravel and sand. Two vertical Ioad tests were performed on plles located under the process buildIng, one at the north end and one at the south end. These showed that one pile behaved as an end-bearing pile while the other emulated friction-pile behavior. These, then, formed the bounding conditions for vertical pile stiffness.

The soll data necessary for calculating stiffnesses for embedded portions of the structure are ahear modulus or shear wave velocity, and Polsson's ratio. As indicated in Ref. 6, the stiffnesses were calcíated based on shear wave velocities determined from in situ measurement. Since these were determined at very low atrains, they were uaed for upper 
bound stiffnesses. To determine stiffnesses conforming to a higher strain, the shear codulus presented In the S.A.R. ${ }^{1}$ (Page II-5-63) was used. This modulus was obtatned from a torslonally exclted; resonant column test. The lower bound stiffnesses were calculated by multiplying the previously calculated upper bound values by the ratio of the two moduli.

Determination of actual in-place. sol1 properties applicable to the dynamic analysis of foundations is extremely difficult. The actual properties of solls are nonlinear (strain-dependent), frequencydependent and load-hIstory dependent. Therefore, all that can be obtained for an elastic analysis is a range of values. For the NFS facility, this range is incorporated Into the calculated range of otiffness coefficients.

PILE STIFFNESS COEFFICIENTS FOR PROCESS BUILDING

Half-space methods require the evaluation of stiffness coefficients to approximate the fixity of the structure attached to the surface of a semi-infinite half-space. The most appropriate method to use for a structure like the process bullding utilizes stiffness coefficlents directly to describe uncoupled 1Inear springs. These are then applied to the foundation boundary nodes of the structural model.
For the determination of vertical plle stiffness, one must determine the form of axtal pile-soll load transfer. For the process bullding, this varles from an end-bearing case to a constant friction case. Therefore, the stiffness varies from $A E / L$ to $2 A B / L$. These form the limiting vertical stiffness values used in the analysis for both the above and below grade portions of the structure. The stiffnesses are effectlve in both tension and compression in the mathematical model even though the stiffness of an actual pile subjected to uplift is not well known. In addition, the connection of the pile to the structure has a very low capacity in tension. Therefore, tension, or uplift, for a pile or pile group was considered a fallure mechanlsm.

The lateral stiffness coefficlents of piles can be calculated by two general methods: considering the pile embedded in an elastic half-space or the beam-on-elastic-foundation method. The most sultable application of the two methods are presented by Poulos for the first method, and by Reese and Matlock for the second method. The solutions incorporating a linearly increasing modulus with depth were utilized. These methods were described and evaluated in Ref. 3. The calculations are Included In UCID-17453, and the results are tabulated in Table 2 . 
Table 2 . Sumary of lateral-pile otiffness.

\begin{tabular}{|c|c|}
\hline ard & $\begin{array}{l}\text { Mit } \\
\text { value, } \\
\text { k/ft: }\end{array}$ \\
\hline $\mathrm{K}_{\mathrm{HX}}-$ Major axis & $40 n$ \\
\hline$K_{\text {HY }}$ - Minor axis & 250 \\
\hline
\end{tabular}

The rangey of values indicated incorporate both the range of soll parameter and the use of two different methods of conputation. These ranges are deemed to incorporate the effects of group action and cyclic load reversal and, thus, should bracket the actual behavior of the foundation system.

The next step in modeling the pile foundation was to incorporate the uncoupled springs into the structural model. This was accomplished by determining the tributary area of each structural node at the foundation, : assuming a homogeneous 'stiffness digtribution, and lumping the appropriate number of pile springs at that node. $I_{1}:$ esulting system resembles that si ur in Fłg. 7 .

EMBEDDED STRUCTURE STIFFNESS COEFFICIENTS FOR LWC AND GPC

The embedded structures consist of portions, of the Liquid Waste Cell (LWC) and the General Purpose Cell (GPC) which Ife below grade. The LWC

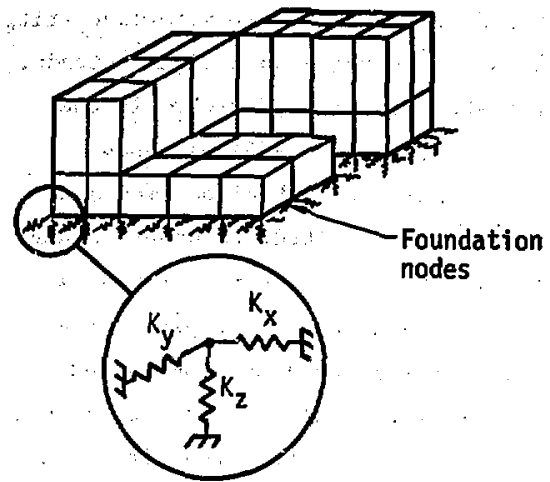

Fig. 7. 'Groups of piles modeled as uncoupled 1inear springs:

is embadded $9.25 \mathrm{ft}$, , and the GPC is embedded $24.5 \mathrm{ft}$. The LWC was Idea1Ized essentially as an axisymetric problem; and the GPC was idealized as both a plane-strain and axisymmetric problem for the two axes of motion to determine embedded lateral stiffness coefficlents. The $1 / 2-1$, insulation board surrounding the GPC was assumed to have no effect on Its stiffness. Two solution techniques were employed:

- Utilization of stiffness coefficients for embedded circular and strip footings determined by static finite element techniques and presented by Johnson, Christiano, and Epstein. 7

- Calculation of stiffness coefflcients based on formulations by Parmelee et a1. ${ }^{8,9}$ for footings resting. on a dynamically loaded half-plane, then modifled for embedment effects. ${ }^{8}$ 
As stated by the euthora, 6-9 an

average constant otiffness coeffictent, Independent of frequency, may be used to determine spring constants for discrete parameter ooll-structure systems subjected to dynamic excltation.

The axisymetric idealizations were formulated in two ways. For one, the equivalent radius was calculated from $\sqrt{\text { area } / \pi}$, resulting in equal stiffness in the two horizontal directions. In an attempt to account for the rectangular shape of the embedded structures, an equivaient radius was calculated for each direction by dividing. the area by the maximum length parallel to the direction of motion. This resulted in a set of values for each direction.

The resulting lateral soil springs were determined by dividing the total resistance among the nodes of each

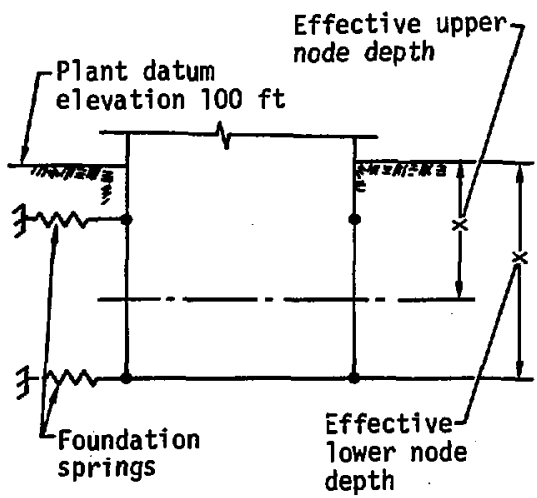

FIg. 8. Embedded structure foundation model. embedded structure. First, the resistance was divided between the lpper and lower portions as shown in Fig. 8 . Th1s was accomplished by considering the upper portion as a Beparate embedded foundation to determine Its contribution in compresaton. This value was then subtracted from the total resistance, calculated earlier, to get the lower portion'a contribution. The springs wers applied to only one side of the footing because the modeled springs act both in tension and compression, while it was assumed that the soll acts in compres. sion only. The upper and lower valucs were then distributed horizontally to each node based on 1ts tributary area.

For the embedded portions, as. for the piles, a range of stiffness values was calculated. This range incorporated two soll moduli, two solution techniques, and two or three geometric idealizations. The highest and lowest values were used in the selsmic analysis. The calculations are included In UCID-17453, and the results are summarized in Table 3 .

Table 3. Summary of embedded structure lateral stiffnesses.

\begin{tabular}{llll}
\hline Cell & Direction & $\begin{array}{l}\text { Min. total } \\
\text { resistence, } \\
\text { K/ft }\end{array}$ & $\begin{array}{l}\text { Max. tota1 } \\
\text { resistance, } \\
\text { K/ft }\end{array}$ \\
\hline GPC & N-S & $5.4 \times 10^{5}$ & $46.5 \times 10^{5}$ \\
& E-W & $2.3 \times 10^{5}$ & $21.4 \times 10^{5}$ \\
LWC & $\mathrm{N}-\mathrm{S}$ & $3.1 \times 10^{5}$ & $10.2 \times 10^{5}$ \\
& $\mathrm{E}-\mathrm{W}$ & $3.5 \times 10^{5}$ & $11.8 \times 10^{5}$ \\
\hline
\end{tabular}




\section{Seismic Analysis Methods}

Selsmic analyses of structural systemp require 1) selection and application of a method of analysis to calculate the structural resporse; 2) construction of a mathematical model of the structure and foundation, and 3) Jefinition of the loading We discuis below the inethodo available for seloivic analygis and the rationale used for selection of a method of analysis. We also Indicate the cholces we made for the NPS factllty.

The purpose of the analysis is to estimate maximum stresses and displacements atd to use these estimates tc assess the safety of the structure. The methods of structural analysis used for selsmic loading can be divided Into two maln categorles: static and dynamic. The static methods of analyals attempt to furnish a distribution of selsmic forces that approximate distributions obtained from dynamic analyses. The dynamic analyses include the inertla effects of the structure as well as the time-varying nature of the forces in the analysis.

Probabilistic methods are also available to conduct selsmic analysis. However, further research in this area tis required before these methods w111 be practical.

The methods of analysis we considered for the NFS facility are shown in Fig. 9.
STATIC METHODS

These methods of analysis are used to obtain a set of static lateral (horlzontal) forces for structural design. The lateral forres are generally asaumed proportional to the weight of the atructure as

$$
F=C^{\prime} W \text {, }
$$

where

$$
\begin{aligned}
F= & \text { total effective equiva- } \\
& \text { lent static lateral force, } \\
W= & \text { weight of structure (in- } \\
& \text { cludes dead welght plus } \\
& \text { percentage of live load } \\
& \text { assumed to be effective } \\
& \text { during an earthquake), } \\
& \text { and } \\
c^{\prime}= & \text { seismic coefficient. }
\end{aligned}
$$
The selection of the seismic coefficient depends on the seismicity and soll characteristics at the site as well as the dynamic characteristics, type, and function of the structure. The major difference between static methods is the way in which the seismic coefficient $G^{\prime}$ is obtained. There are two ways commonly used to obtain a value for $C^{\prime}$ : the Uniform Butlding code ${ }^{10}$ approach and the maximum horizontal ground-motion approach. Both of these methods assume the structural behavior is governed by the response of the first furdamental mode of vibration. 


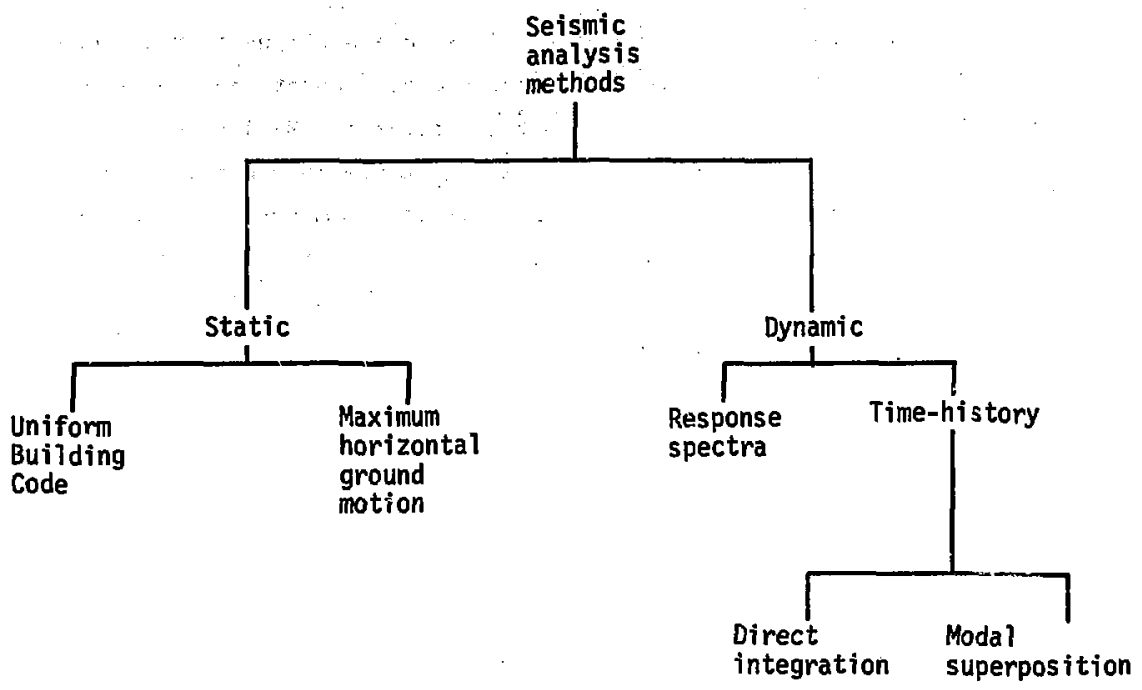

Fig. 9. Selsmic analysis methods.

Uniform Building Code Approach

The method of selsmic analysis spectfied in the Uniform Bullding Code is a static method intended for the design of most residential, industrial and commercial structures in the United States.

This approach provides minimum standards so that structures will resist:

- Minor earthquakes without damage.

- Moderate earthquakes without structural damage

- Major earthquakes without collapse (but possibly severe structural damage).

Many municipaj.ities adopt the Uniform Building Code for minimum design requirements.
It is not reasonable to use the Uniform Building Code approach directly for the design or analysis of critical structures in nuclear facilities. These structures are different from those on which the Bullding Code is based. Moreover, critical nuclear facilities are required to function during and after a strong earthquake, with little or no structural damage.

Maximum Horizontal Ground-Motion Approach

Another approach to static analysis 1s to use the meximum horizontal acceleration postulated for the site as the selsmic coefficient $C^{\prime}$. This would better incorporate the local 
selamiclty of the area Into the analyals but would not Include the dynamic characterfotics of the structure. In many cases, thls is an acceptable approacl for stiff structures on rigid foundations (1.e., systems with frequenctes greate: than $33 \mathrm{~Hz}$ ). The set of static forces for design could be obtalned by the Building code method of distribution.

This pethod would not be used if dynamic amplification or soil-structure Interaction is an imfiortant factor.

\section{DYNAMIC METHODS}

Dynamic methods of analysis determine the distribution of forces in a structure by Including the dynamic characteristics of the structure (mass, damping, and stiffness) in the equations of motion. The following methods are generally employed.

Response : Spectrum Method

This is an approximate method of analysis that requires an acceleration response spectrur as a description of the ground motion. Mode shapes and frequenclas of the mathematical model must be calculated. The solution is obtained by calculatIng the response (1.e, displacement, acceleration, and stress) In each mode and then adding up the modal responses to get the total response.
This mode superposition is usually achleved by a square root of the sumof-the-squares (SRSS) procedure. This procedure is modified when closely spaced modes occur In a problem. ${ }^{11}$ This method of analysis 18 approximate because of the way the modal quantities are combined to get the total response. The SRSS procedure of combining modal quantities is ured since the maximum value in each mode may not occur at the same time. Enough modes must be included in the analysis to capture the complete structural response.

The advantages of this approach over static methods are 1) the mass and the stiffness characieristics of the structure can be included in the analysis, 2) the foundation compliance can be modeled (In a linear manner), and 3) the nitiod permits the Incorporation of lile site response characteristics.

Time-History Methods

The time-history method of analysis is an exact rethod for determining the structural response to a known forcetime history or acceleration-time history.

A time-history analysis is conducted by one of two approaches: mode superposition ór direct integration. The mode superposition approach solves the eigenvalue problem associated with the model to deternine the mode shapes 
and frequencles of vibration. The response in each mode is determined axis combined to get the total response. This method is 1imited to the 11near response of structures.

The direct integration method is used to obtain a colution by step-bystep integration of the equations of motion directly. Solution of the elgenvalue problem 1s not required, and nonlinear effects may be included tf required.

A direct integretion analysis is equivalent to an analysis by the mode superposition approach in which all mode shapes and frequenctes are included and the same time step $\Delta t$ is used. Both methods involve a large amount of computer time to solve for the dynamic response of a structure since small time steps are required to acileve meaningful results. Both methods also require knowledge of acceleration-time history Input. Table 4 compares some of the advantages and disadvantages of these methods.

\section{ANALYSIS OF THE NFS FACILITY}

For analysis of the NFS faciltty, we chose to conduct a dynamic analysis by the response spectra approach. He felt this provided a practical and econonical way to get a realistic estImate of the structurai response and the onset of fatlure without having to choose or synthesize accelerationtime historles. This approach reduces the computation effort required to get a solution as wel.1 as the time required to display and interpret the results.

Our analys1s wi1 1nvolve approximations since we are using a linear elastic procedure to assess the onset of fallure. Theoretically, when one element falls, or comriences inelastic behav'ir, a linear elastlc analysis is no longer valid, In reality, however, a certain amount of nonlinear behavior will not apprectably affect the response of the rest of the structure. We feel our analysis will Indicate weak areas in the structure and will provide estimates of the heglining of failure.

We examined the effect of the number of modes included $I a$ the study by running one case with 10 and 20 modes and comparing the displacement responses. Since both responses were reasonably close, we chose to use 10 modes for affictency.

COMPUTER PROGRAMS USED IN STRUCTURAL ANALYSIS

The structural analysis can be performed by many avallable computer prograns. We conducted our analysis with the SAP IV ${ }^{12}$ program. SAP IV is a structural analysis program for computing the static and dynamic response of three-dimensional IInear 
Table 4. Advantages and disadvantages of methods of analysis.

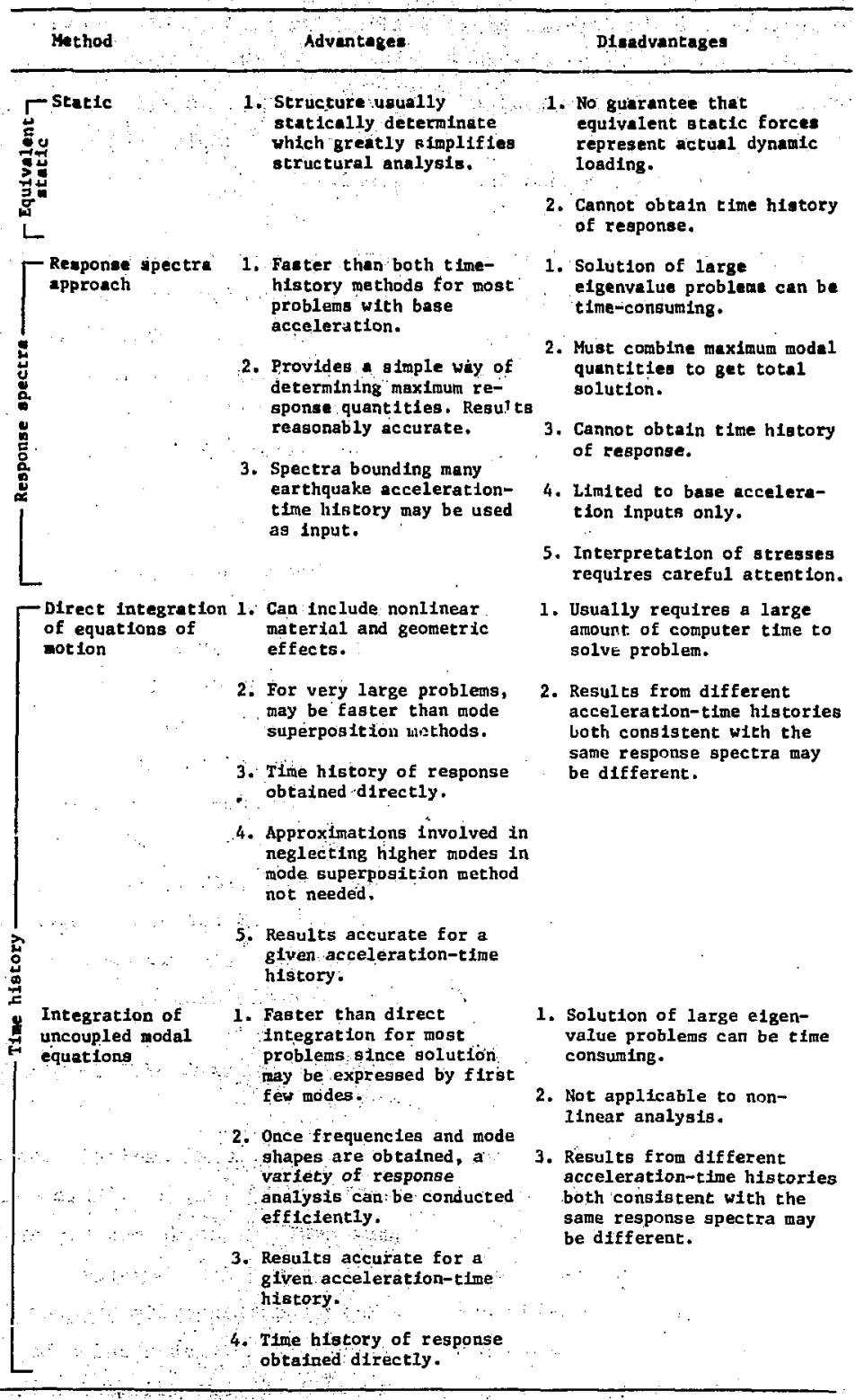


aystens. The etructural systen that can be annlyzed way be modeled with. a combination of different structural elements. The progran contains the following elements: truss element, beam element, plane stress, plane strain, and axisymmetric solfd elements, 3-D solid element, thick shell element, thin plate or shell element, pipe element, and boundary element. They may be used to model problems for static or dynamic analyses.

SAP IV can solve static problems and has three solution options for dynamic problems: response spectra analysis, and time-history analyses by mode superposition, and direct integration.
We used SAMPP ${ }^{13}$ (StructuralAnelysis Novie Postprocessor) in conjunction with PREPOST ${ }^{14}$ for plotting the finite element model and Its response, PREPOST processeg SAP IV regults for Input to SAMPP and calculates maximum shear stresses.

SAMPP Is a general purpose routine for the display of three-dimensional, finite element models and the results from both static and dynamic analyses. The program may be used to produce IIne drawings as well as animated line-drawing movie sequences. SAMPP uses a hldden-surface processor for the display of realistic perspective views.

\section{Structural Loading}

DEAD IOAD

A static dead-weight analysis was conducted on the model to estimate the Inftlal state of stress prior to the selsmic event. This analysis Included the welght of the structure and supported equipment. The weight was increased uniformly to account for the percentage of live load that may be acting on the structure during an earthquake.

Our estimates of dead weight are as accurate as the construction drawings supplied to us by NFS for the primary structural elements within the constraints of our model. Data supplied by DRAvo for equipment masses were used directly.

\section{SEISMIC LOAD}

We needed seismic input for the structural analysis. Since there are no existing guidelines for the selection of the seismic input for fuel reprocessing plant structures, we had two alternatives: 1) to select recorded earthquake accelerograms and generate response spectra, or 2 ) to 
derive an accelerogran that gtatist1cally represento a typical accelerogram. We have chosen the latter approach. Rather than perform the statistical calculations ourselves, we have, for convenience, used the Information In USNRC Regulatory GuIde $1.60 .^{15}$

Guide 1.60 defines the selsmic input to nuclear power reactors based on a statistical treatment of some 50 earthquake records. It gives both the hortzontal and vertical response spectra for different values of structural damping. Both are normalized to a maximum horizontal ground acceleration of $1.0 \mathrm{~g}$. Once the intensity of ground motion for a site is specified in terms of maximum horizontal ground acceleration, both horizontal and vertical spectra can be defined simply by scaling.

The spectra given in Guide 1.60 are based on values one standard deviation over the calculated mean values of spectral acceleration. Guide 1.60 is Intended for sites underlain by either rock or soil deposits, and it covers all

frequencles of interest. For unusually soft sites, modification of this procedure is required.

We have used the Guide 1.60 values to define our input response spectrum. There are no data for determining whether thls spectrum Is conservative for the NFS atte or not However, the same spectrum is used for design of nuclear power plants In the Eastern United States so Its use at the NFS site is constdered reasonable.

Dampling values used are consistent with Regulatory Guide $1.61^{16}$ (shown In Table 5), which delineates damping values acceptable for elastic dynamic analyois. The damping values account for energy dissipation and reflect both material and structural damping for stresses less than yleld.

In this study we selected a dampIng ratio of $7 \%$ to account for the relifforced corcrete structure and the foundation interaction.

The horlzontal acceleration response spectrum used in this study Is shown in Fig. 10. This spectrum was used as input in both the northsouth and east-west directions, and two-thirds of $1 t$ was used as input for the vertical motion. The input motion was applied to the structure uniformly at foundation level.

In FIg. 11, we compared the Regulatory Guide spectrum with the spectrum at foundation level computed from an analysis of the West Valley site conducted by IASL. 17

The shapes of these spectra are comparable in the range of periods of 0 - to 0.45-sec. At periods greater than $0.45 \mathrm{sec}$, the LASL generated spectrum bounds the Regulatory Gulde spectrum: The range of fundamental periods of the four cases we studied 
Table 5. Damping values. 16

Operating basis

ear thquake or $1 / 2$ safe

Safe shutdown

shutdown earthquake

earthquake

Structure or component

Percent of critical damping

Equipment and large-dlameter

piping systems, pipe diameter

greater than 12 in.

Small-dLameter piping systems, diameter equal to or less than

12 In.

Welded steel structures

Bolted steel structures

Prestressed concrete structures

Reinforced concrete structures

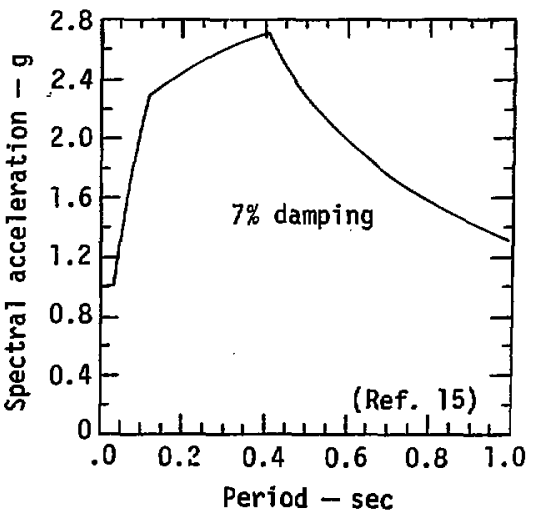

Fig. 10. Horizontal acceleration response spectrum normalized to $1 \mathrm{~g}$ used in the analysis of the NFS facility.

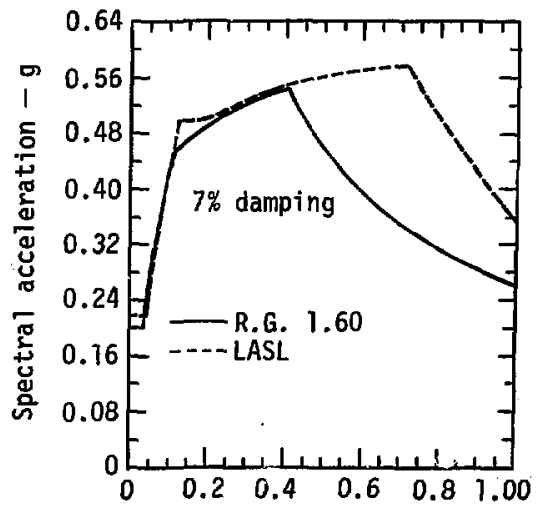

Period - sec

Fig. 11. Comparison of Regulatory Guide 1.60 spectrum with LASL-generated spectrum. 
was 0.22 to $0.50 \mathrm{sec}$. In this range, the spectra are comparable. Thus, the application of the Gilde 1.60 surface apectrum at foundation level appears reasonable.

CONBINATION OF EARTHQUAKE COMPONENTS

When a response spectrum analysis is conducted, there are two methods commonly used to combine the structural response caused by horizontal and vertical earthquake motions. These methods are summarlzed below:

- Method of Linear Addttions The maxima in each direction are combined directly. This method provides a conservative estimate of the response since each of the maxima in the three orthogonal directions do not necessarily occur simultaneously.

- Square Roof of the Sum-of-theSquares (SRSS) Method - This method attempts to estimete the most probable response of the structure by combinIng the maximum values in a way that recognizes that these values do not occur Bimultaneously.

For analysis of the NFS facility, we chose to use the more conservative component combination scheme: the method of Iinear additions. This decision was made to keep the number of computer runs down and to avold developing a program to perform the SRSS procedure for earthquake component combinations.

COMBINATION OF DEAD AND SEISMIC LOADING

Results of the selsmic analyses were combined with the dead-load analysis results to estimate the worst-case loading situation. Results were not scaled by load factors.

\section{Analyses Conducted}

We conducted a static dead-load analysis and several dynamic analyses (all Inear-elastic) to determine the total state-of-stress, including foundation effects, during an earthquake.

The selsmle ansiysis of this facility resulted in the solution of four separate problens. These four cases developed from considering the upper- and lower-bound values for embedded structure spring stiffness and pile spring stifeness (vertical as well as latera1). These maximum and minimum values were determined to bound the vartations expected in 
sot1-structure interaction. These four cases are summarized In Table 6 .

We then combined the dead-load. results with the results of the four dynamic analyses. Acceleration levels at the onset of fallure were determined by comparison with threshold of failure values. The threshold of failure shear values were determined as follows:

$$
\tau_{\max } \sqrt{\left(\frac{\sigma_{x} \pm \sigma_{y}}{2}\right)^{2}+\tau_{x y}^{2}}
$$

where

$$
\begin{aligned}
\sigma_{x}, \sigma_{y}- & \text { normal stress } \\
& \text { components in the } \\
& \text { x and } y \text { directions } \\
\tau_{x y} \quad & \text { shear stress acting } \\
& \text { with the normal } \\
& \text { stresses. }
\end{aligned}
$$

The response spectrum analysis gives the magnitude of $\sigma_{x}, \sigma_{y}, \tau_{x y}$; however, their sign is lost. 18 Th1s fact results in two unique values for the calculated maximum shear stress. The maximum of the two values is the quantity compared with the ultimate values.

Table 6. Summary of foundation model cases for selsmic analysis.

\begin{tabular}{ccc}
$\begin{array}{c}\text { Embedded } \\
\text { structures }\end{array}$ & $\begin{array}{c}\text { Minimum } \\
\text { embedded structure } \\
\text { stiffness }\end{array}$ & $\begin{array}{c}\text { Maximum } \\
\text { embedded structure } \\
\text { stiffness }\end{array}$ \\
\hline
\end{tabular}

\section{Case 3}

This case was belleved to provide the maximum load to the upper areas of the

Minimum pile stiffness facility (shear-wall faflures).
Case 1

Th1s case was selected to represent the worst loading for the embedded structures and also represent pile tension failure from rocking.

\section{Case 2}

This case was belleved to

Maximum pile st Iffiness represent the worst loading case for lateral pile springs (Lateral PIle Failure).

\section{Case 4}

It was felt that this case could produce shear wall failures where cases 1 and 3 did not.

\section{Failure Definition}

The purpose of conducting the seiswic analysis was to determine the peak ground acceleration level that would
Initiate fallure of the structure. The primary consideration for evaluating the performance of the structure 
was Its abllity to provide confinement for radioactive materials, Therefore, 1t was dec1ded that excesalve cracking of elements providing. confinement would provide the primary criterion for determining the onset of fallure. It ls our bellef that state-of-the-art methods for selsmic anslysis are not sufficiently developed to allow determination of the size of cracks formed during an earthquake. The second area for investigation was to point out regions of structural weakness, not necessarily directly related to confinement.

It is important to recognize that an aralyas to determine actual fallure of an existing otructure is considerably different from an analysis for deslgning a new structure. For design, load fäctors and conservative assumptions are used to ensure that a fallure level will not be reached. For fallure analysis, one must attempt to determine the conservatism and safety factors in allowable or ultimate values specified in building codes so that they may be removed. For example, $\mathrm{flg}_{\mathrm{g}} 12$ gives en indicathon of differences between the actual faflure levels of concrete shear walls and the atrengths predicted by deign formilas.

The potentsal modes of fatlure for the wF Proces Butlding Include: Relnforced concrete shear wall fallure.
Concrete block shear fallure.

- Foundation fallure.

- Large relative displacements at sliding folnts.

The fourth fallure mode will not be addressed herein because the model has rigid connections and camnot simulate sliding joints. The criteria for evaluating the flrist three fallure modes will be discugsed separately.

REINFORCED CONCRETE SHEAR WALL FAILURE

The onset of fallure for relnforced concrete was defined to be the point where the unfactored loads became equal to the ultimate strength of the structural elements. The ultimate shear strength was computed based on provisions of the ACI specifications, 20 ACI background paper, ${ }^{19}$ SEAOC code, ${ }^{21}$ Joint ASCE-ACI Task Committee 426 (ref. 22), and Uniform Butlding Code. ${ }^{10}$ The code ultimate-strength values are modified by a capacity reduction factor $\phi$, which provides for variations in materlal strength, workmanshlp, and dimensions. It is generally recoginized that the strength of concrete increases with age. Th1s, combined w1th an assumption of standard workmanship led to the adoption of $\phi=1$ for process buflding components.

The Acr provisions for shear capacity relates primarily to static cases. The ultimate capacity, v, is composed of two componenta: 


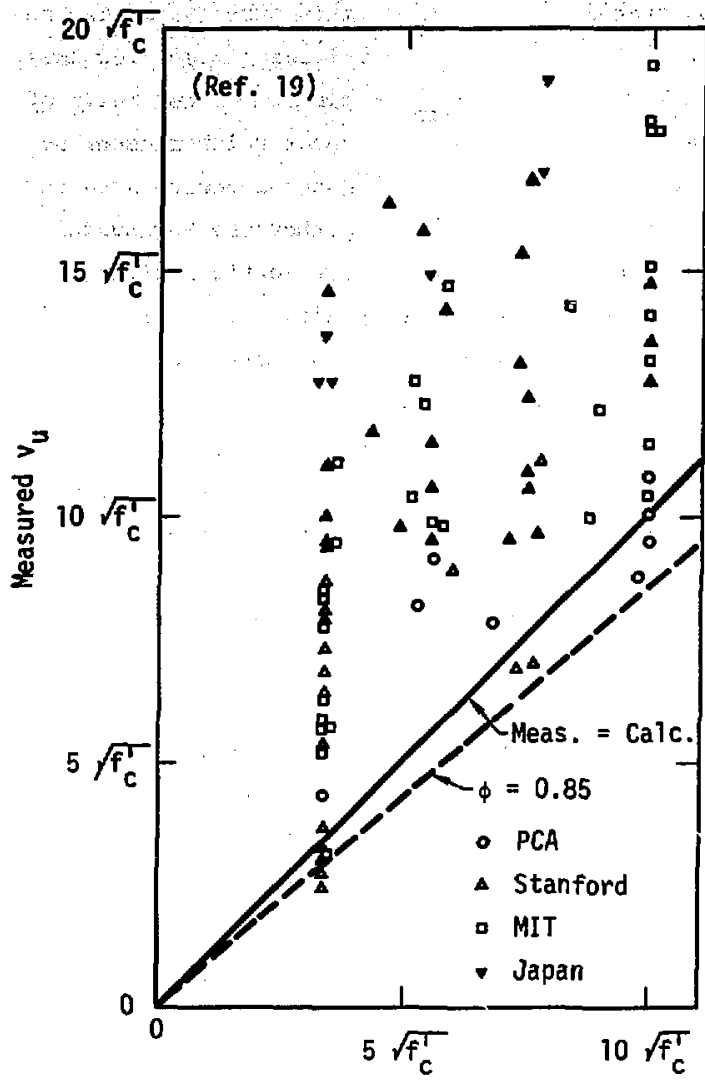

Fig. 12. Compariaon of merisured and calculated ohear atrengtho ( $f^{\prime}$ - compressive stfength of the concrete and $v_{u}=u 1 t i-$ mate shear $u$ trength).

Calculated $v_{u}$

$$
v_{u}=v_{c}+v_{s}
$$

where $v_{c}$ is the capacity of the concrete in diagonal tension and $v_{s}$ is the capacity of the horlzontal reinforcement in the wall. The ohear capacity of the concrete is Influenced by axlal: and flexural forces. For NFS, it was assumed that the crosswalls act as flanges to resist any flexural and axfal forces. Therefore, axial and flexural contributions were not considered in the calculation of shear capacities.

ACI $^{19,20}$ indicates that $v_{c}$ may be taken as $2 \sqrt{f_{c}^{\prime}}$ if the wall is not in tension. The SEAOC code says that the ultimate concrete shear should not 
exceed $v_{c}=2 \sqrt{E_{c}}$ Thts Is also stated In the Corbitte 426 report for wills subjected to Ioad reversals, which also atatea that the total $v_{u}$ should be Ifmited to $8 \sqrt{\mathrm{f}^{2}}$. It was the consensus of the references that to develop fully the capacity of the horizomcal reinforcement in resisting shear forces, an equal amount of vertical reinforcement ahould be provided. Therefore, for this structure, only the portion of horizontal Bteel area matched by vertical steel was used to determine the shear capacity caused by the steel. That is,

$$
v_{s}=\rho_{\min } f_{y},
$$

where $\rho_{\min }$ was determined for each element by taking the minimum ratio of steel area to gross concrete area, considering both vertical and horizontal steel as shown on the plans and $f_{y}=$ yield strength of the reinforcement. Thus, the ultimate shear strength was determined from

$$
v_{u}=v_{c}+v_{s}
$$

or

$$
v_{u}=2 \sqrt{f_{c}^{\prime}}+\rho_{\min } f^{\prime}
$$

where

$$
\begin{aligned}
& f^{\prime}-\text { compressive strength of } \\
& \text { the concrete }(2500 \mathrm{ps})
\end{aligned}
$$

$$
\begin{aligned}
f_{y_{i}}= & y i e l d \text { strength of the re- } \\
& \text { inforcing steel ( } 60 \mathrm{ksi}), \\
\rho_{\text {min }} & \text { minimum of the ratio of } \\
& \text { shear reinforcement to } \\
& \text { gross concrete area in } \\
& \text { either the horizontal or } \\
& \text { the vertical direction. }
\end{aligned}
$$

The resulting ultimate shear capacities may seem conservative based on code static design values. However, consideration of energy absorption, flexural strength, and relnforcement detalls dictate these stress levels.

CONCRETE BLOCK SHEAR WALL FAILURE

The allowable working stress values for masonry walls in shear were calculated in accordance with the provisions of the Reinforced Masonty Engineering Handbook. 23 The following assumptions were employed:

- The ultimate compressive masonry strength, $f_{m}^{\prime}=1500$ pst.

- All masonry units are grouted sclid with concrete of grade $A$ or $N$.

- Special Inspection was employed. All shear stresses are carrled by masonry and grout, none by reinforcement.

The measure of failure of the concrete block shear walls was the attaiment of their ultimate strength, which was estimated by multiplying the working atress values by a factor of two. Thls value was obtained from people 
knowledgeable in the field of masonry construction. 24

\section{FOUNDATION FAILURE}

The direct consequences of fallure of portions of the foundation are difficult to determine. However, there are two potential effecta of foundation fallure. One is the effect on the integrity of the rest of the structure, and the other is the effect on the validity of an elastic analysis subsequent to fallure. As a result of discussiong with NRC and LASL, ${ }^{2}$ it was decided that $10-15 \%$ of the piles could fatl before the rest of the structure would experience a significant effect. For this study, we decided to report the oriset of foundation fallure by using the $10 \%$ figure while allowing the elastic analysis to continue until the $15 \%$ fallure level was reached.

The fallure modes for piles were divided Into two parts, vertical and 1ateral. The vertical fallure mode occurs as a result of the connections between the piles and the structure. There is virtually no tensile capacity for this foint which could result in separation of the building and pile during rocking motion. Impact loads that could result during subsequent load cyclea were considered unacceptable. Therefore, the attainment of tension in a pile was defined as failure for that pile.
A lateral pile fallure could result from pile-cap tearout, shear In the pile, or axial load-bending moment Interaction. The controlling failure mode was the onset of yieldIng caused by axial load-moment interaction. The moments in the piles subjected to lateral force were determined by beam-on-elasticfoundation techniques. The calculations for the varlous conditions and the resulting maximum capacities are given in UCID-17453.

DETERMINATION OF FAILURE LEVEL

The initial structural loading was determined by conducting a static dead-1oad analysis as well as a $0.2 \mathrm{~g}$ peak ground acceleration dynamic analysis for each case. Because a linear slastic response spectrum analysis technique was employed, dynamic loads for other peak ground accelerations may be obtained by direct proportion.

The stresses from the structural loading were compared with uItimate values for each oi the elements. If the maximum ultimate value for an element was exceeded, the dynamic load contribution was linearly proportioned until the sum of static and dynamic loads equaled the ultimate. This defined the peak ground acceleratIons at the onset of failure, which are the values reported. 


\section{Results}

The analysia of the NFS factilty ylelded several points of interest. One Interesting Iten ts that by varyIng the parameters that govern the soll-structure interaction phenomena, any one of the first three modes of vibration can be tuned to the period where the peak spectral accelezation occurs. Fig. 13 11lustrates rocking and twisting modes referenced to the major axes of the structure.

Figures 14 through 17 show how the periods of the structure vary from one foundation case to another. It can be shown that the first three modes for each of the cases are caused primarily by sof1-structure interaction. For example, the fundamental

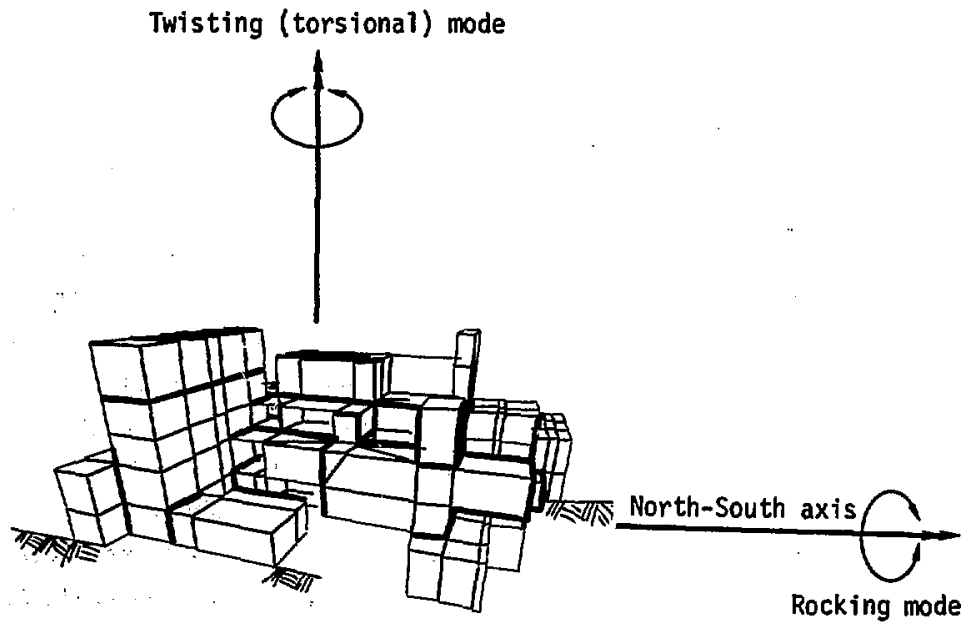

Rocking mode

Fig. 13. Major axes of the structure showing rocking and twisting mode. 


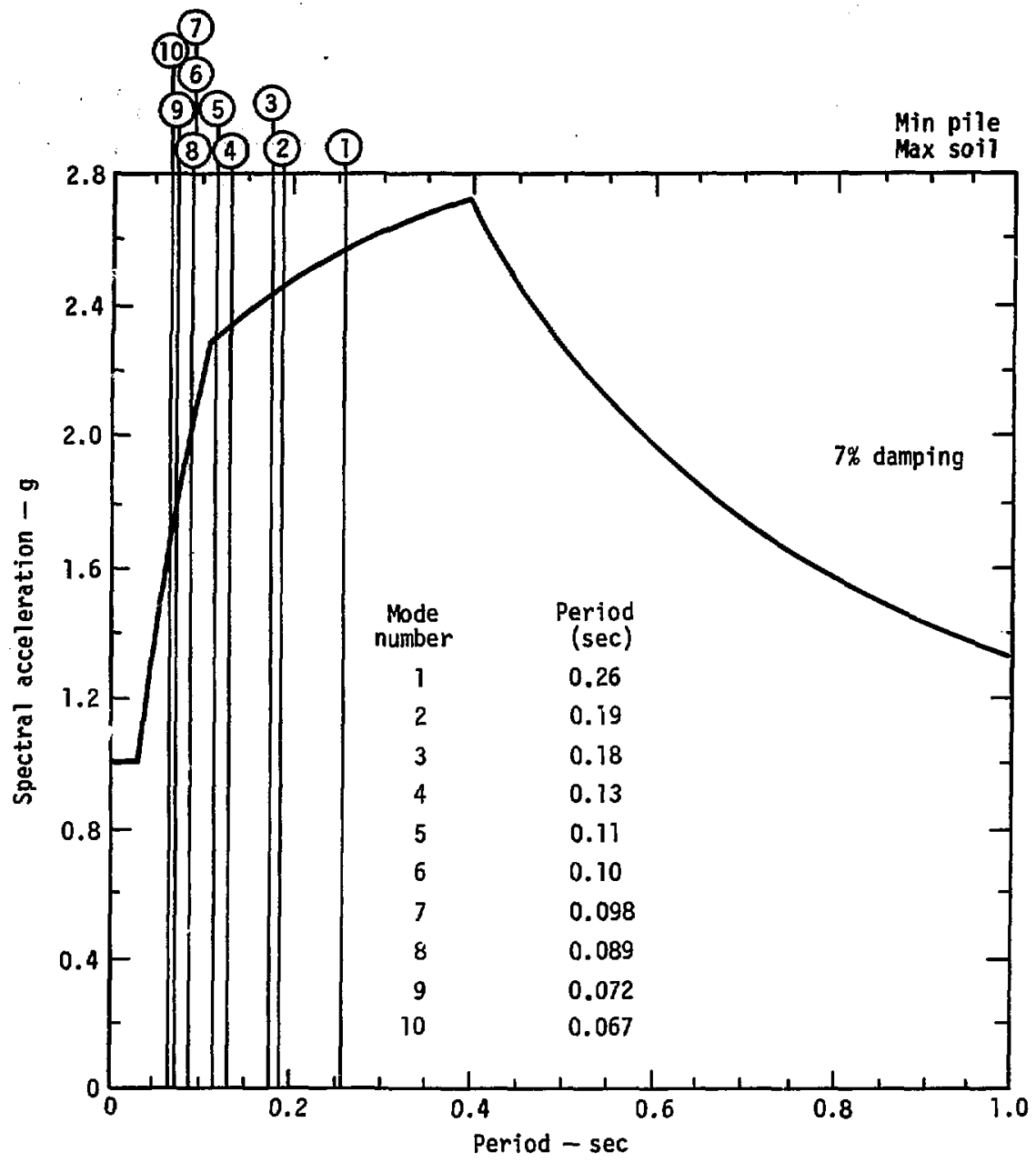

Fig. 14. Case 1 Input spectrum with perlods of the first ten modes superimposed. 


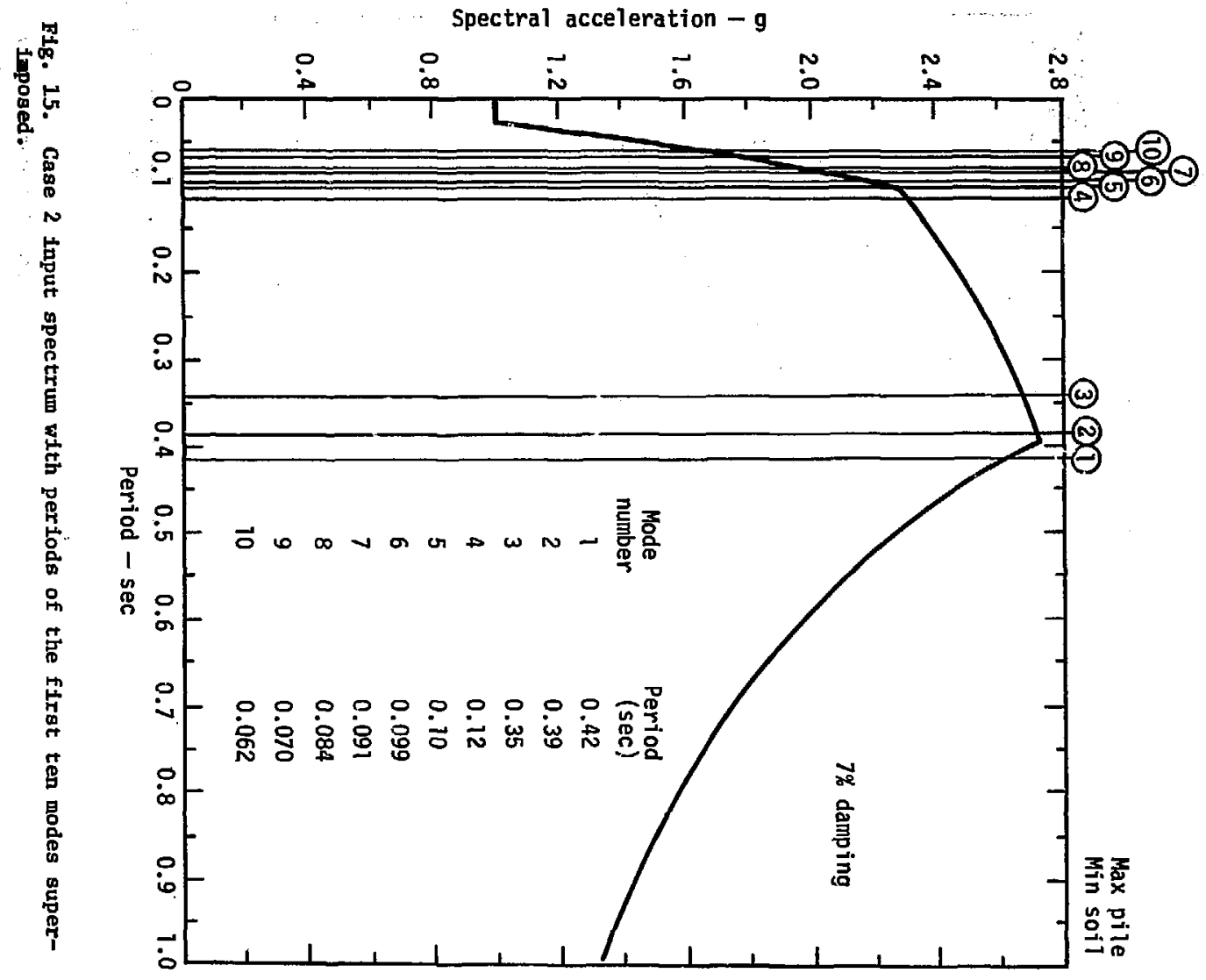




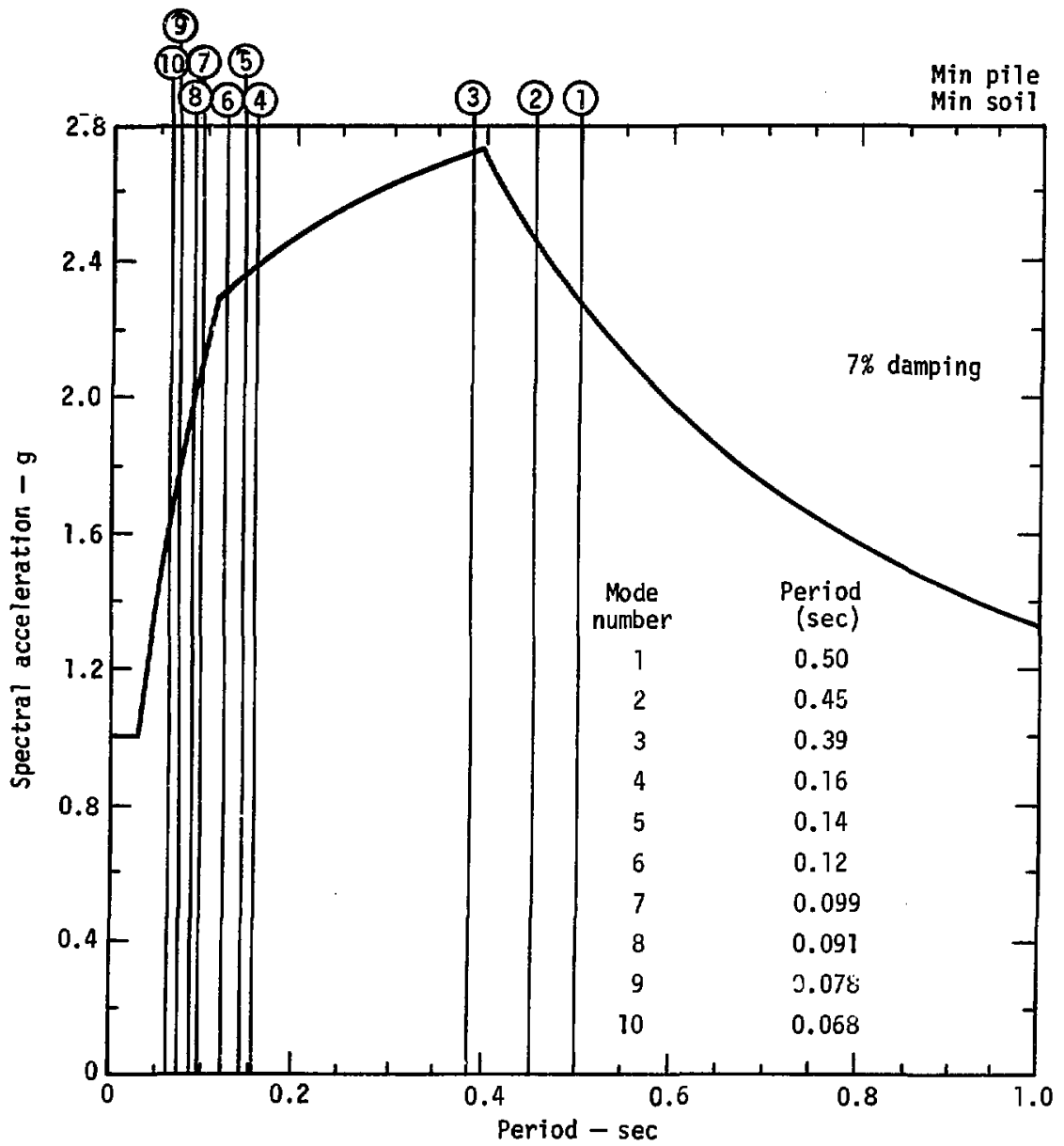

Fig. 16. Case 3 Input spectrum with periods of the first ten modes superimposed. 


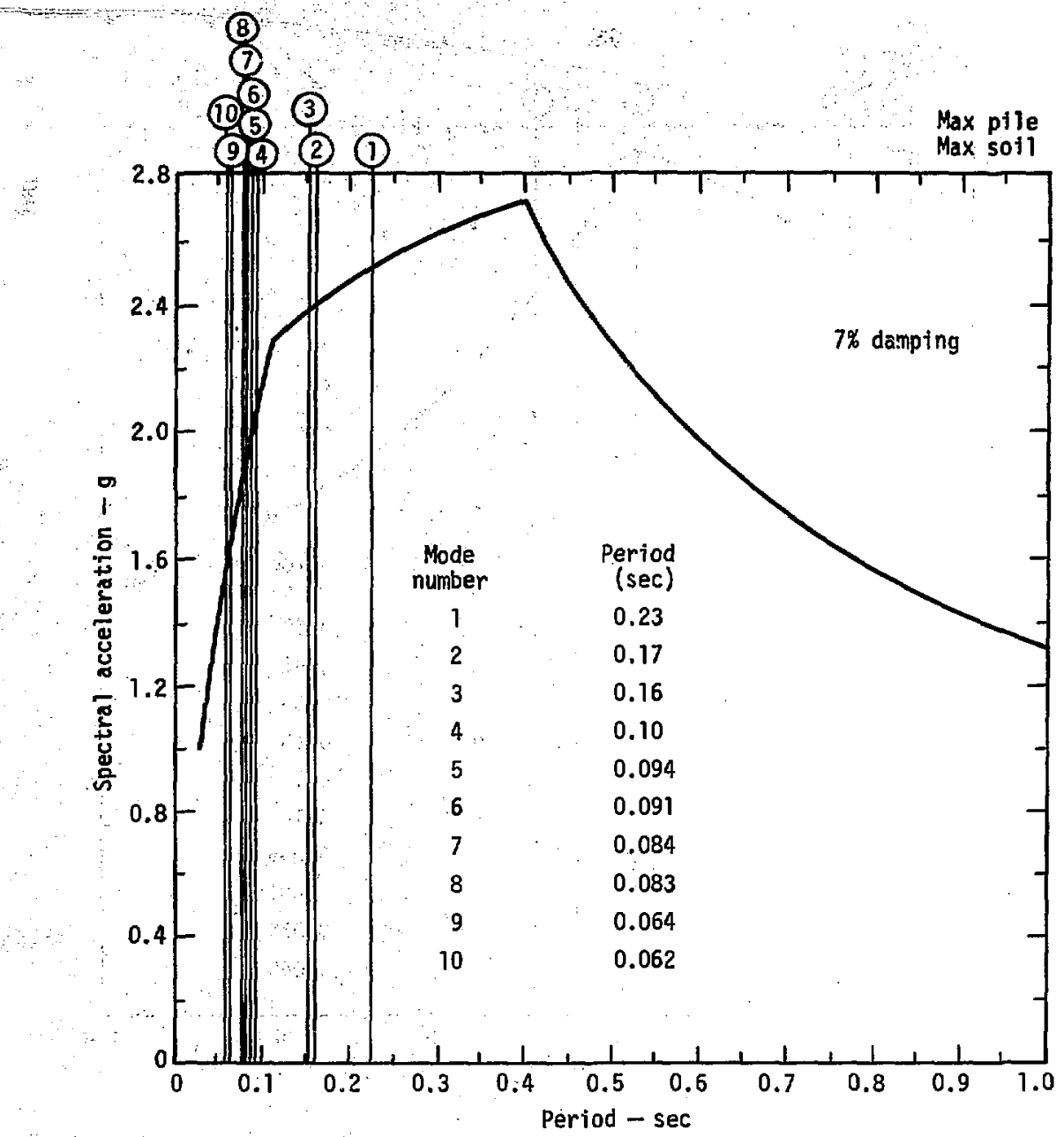

Fig. 17. Case 4 input spectrum with periods of the first ten modes superImposed. 
mode for case one (FIg. 14) 1s prinarily a rocking node about a northsouth axts. Hode two is primarily a rocking node about an enst-weat axis while mode three is twisting about a vertical axis. The first three modes for cases two and three (FIgs. 15 and 16) Involve essentially the same type of motions. Hode one 18 basteally twisting about a vertical axis while modes two and three are primarily translations back and forth in an east-weat and north-south direction, respectively. Case four (Fig. 17) has a fundamental mode that is primarily twisting about a vertical axis whlle modes two and three are a combination of rocking (about a northsouth axis and about an east-west axis, respectively) and twisting about a vertical axis.

The basic items of concern for this analysis are the various types of fallure. The investigation determined that there are four potential types of fallure. These are shear wall and pile tension fallure, lateral failure of piles, and PMC-to-GPC connection failure.

\section{SHEAR WALL FAILURE}

The shear walls for the facility consist of reinforced concrete block walls as well as the poured-in-place reinforced concrete walls of the major cells. The ons 5 of fallure for the elements that exceed their maximum ultimate shear stress at or below a peak ground acceleration of $0.2 \mathrm{~g}$ are given in Table 7. The location of some of these elements within the facility as well as the ranges where the onset of fallure occurs are shown for the varlous caged in Figures 18 through 21. The ultimate shear stress value for each element is given in UCID-17453.

The data generated for the four cases indicate that the concrete block shear walls begin to fail at about 0.03 to $0.07 \mathrm{~g}$. The two areas whe:e this occurs are the shielding door tower $(0.03 \mathrm{~g})$ on top of the CPC and the exterior walls of the $A O C$, $(0.07 \mathrm{~g})$.

The onset of failure for the reinforced concrete walls first occurs in the GPC at about $0.09 \mathrm{~g}$. The other major cells that have elements where the onset of fallure occurs prior to a $0.2 \mathrm{~g}$ ground acceleration are the LWC and the CPC.

If the maximum allowable shear stress in the south wa11 of the CPC is $50 \mathrm{psI}$ (as Indicated in the Dravo Report), rather than 267 psI, our analysis indicates the onset of fallure for these elements will occur at approximately $0.08 \mathrm{~g}$.

\section{PILE TENSION FAILURE}

Figures 22 through 25 show the location of the modeled pile springs 
Tab1e. 7. Peak ground acceleration where the onset of fallure in shear elements occur ( $\left.g^{\prime} \mathrm{s}\right)$.

\begin{tabular}{|c|c|c|c|c|c|c|c|}
\hline ce11 & $\begin{array}{l}\text { Elem. } \\
\text { no.: }\end{array}$ & $\begin{array}{c}\text { Case } 1 \\
\because 8\end{array}$ & $\begin{array}{l}\text { Case 2, } \\
\text { g }\end{array}$ & $\begin{array}{c}\text { Case 3, } \\
\text { g }\end{array}$ & $\begin{array}{c}\text { Case } 4 \text {, } \\
8\end{array}$ & $\begin{array}{c}\text { Min } \\
\mathbf{g}\end{array}$ & $\begin{array}{c}\text { Absolute } \\
\text { min, } g\end{array}$ \\
\hline $\begin{array}{l}\text { } \\
\text { AOC } \\
\text { (concrete } \\
\text { block) }\end{array}$ & $\begin{array}{r}2 \\
3 \\
5 \\
6 \\
8 \\
11 \\
14 \\
15 \\
20 \\
24 \\
25\end{array}$ & $\begin{array}{l}0.08 \\
0.15 \\
0.12 \\
0.16 \\
0.11 \\
0.07 \\
0.07 \\
0.19 \\
0.12 \\
0.11 \\
0.12\end{array}$ & $\begin{array}{l}0.11 \\
0.20 \\
0.17 \\
0.25 \\
0.17 \\
0.08 \\
0.07 \\
0.24 \\
0.14 \\
0.16 \\
0.15\end{array}$ & $\begin{array}{l}0.10 \\
0.19 \\
0.17 \\
0.23 \\
0.16 \\
0.08 \\
0.07 \\
0.23 \\
0.14 \\
0.17 \\
0.14\end{array}$ & $\begin{array}{l}0.08 \\
0.14 \\
0.12 \\
0.17 \\
0.11 \\
0.07 \\
0.07 \\
0.19 \\
0.12 \\
0.12 \\
0.11\end{array}$ & $\begin{array}{l}0.08 \\
0.14 \\
0.12 \\
0.16 \\
0.11 \\
0.07 \\
0.07 \\
0.19 \\
0.12 \\
0.11 \\
0.11\end{array}$ & 0.07 \\
\hline CPC & 43 & 0.19 & 0.15 & 0.16 & 0.15 & 0.15 & 0.15 \\
\hline LWC & $\begin{array}{l}181 \\
186 \\
223 \\
231 \\
233\end{array}$ & $\begin{array}{r}0.09 \\
0.09 \\
0.09 \\
0.24 \\
\therefore \quad 0.12\end{array}$ & $\begin{array}{l}0.29 \\
0.29 \\
0.22 \\
0.24 \\
0.35\end{array}$ & $\begin{array}{l}0.30 \\
0.31 \\
0.25 \\
0.24 \\
0.35\end{array}$ & $\begin{array}{l}0.10 \\
0.10 \\
0.10 \\
0.19 \\
0.13\end{array}$ & $\begin{array}{l}0.09 \\
0.09 \\
0.09 \\
0.19 \\
0.12\end{array}$ & 0.09 \\
\hline GPC & $\begin{array}{l}273 \\
274 \\
276 \\
289 \\
290 \\
291\end{array}$ & $\begin{array}{l}0.09 \\
0.14 \\
0.17 \\
0.17 \\
0.17 \\
0.11\end{array}$ & $\begin{array}{l}0.10 \\
0.14 \\
0.16 \\
0.15 \\
0.15 \\
0.11\end{array}$ & $\begin{array}{l}0.09 \\
0.14 \\
0.15 \\
0.15 \\
0.14 \\
0.11\end{array}$ & $\begin{array}{l}0.09 \\
0.13 \\
0.16 \\
0.15 \\
0.13 \\
0.10\end{array}$ & $\begin{array}{l}0.09 \\
0.13 \\
0.15 \\
0.15 \\
0.13 \\
0.10\end{array}$ & 0.09 \\
\hline $\begin{array}{l}\text { TOP } \\
\text { (concrete } \\
\text { block) }\end{array}$ & $\begin{array}{l}308 \\
309 \\
310 \\
311 \\
312 \\
331 \\
332 \\
333 \\
334\end{array}$ & $\begin{array}{l}0.13 \\
0.06 \\
0.03 \\
0.06 \\
0.07 \\
0.13 \\
0.07 \\
0.14 \\
0.07\end{array}$ & $\begin{array}{l}0.21 \\
0.12 \\
0.06 \\
0.12 \\
0.13 \\
0.29 \\
0.14 \\
0.31 \\
0.16\end{array}$ & $\begin{array}{l}0.28 \\
0.26 \\
0.12 \\
0.21 \\
0.22 \\
0.71 \\
0.26 \\
0.72 \\
0.43\end{array}$ & $\begin{array}{l}0.17 \\
0.15 \\
0.08 \\
0.15 \\
0.14 \\
0.40 \\
0.18 \\
0.41 \\
0.24\end{array}$ & $\begin{array}{l}0.13 \\
0.06 \\
0.03 \\
0.06 \\
0.07 \\
0.13 \\
0.07 \\
0.14 \\
0.07\end{array}$ & 0.03 \\
\hline
\end{tabular}

Case 1 = minimun plle/maximum embedded stiffnesses. Case 2 = maximum pile/minimum embedded stiffnesses. Case $3=$ minimum $p 11 \mathrm{e} / \mathrm{min}$ inum embedded s.tiffnesses. Case $4=$ maximum pile/maximum embedded stiffnesses. 

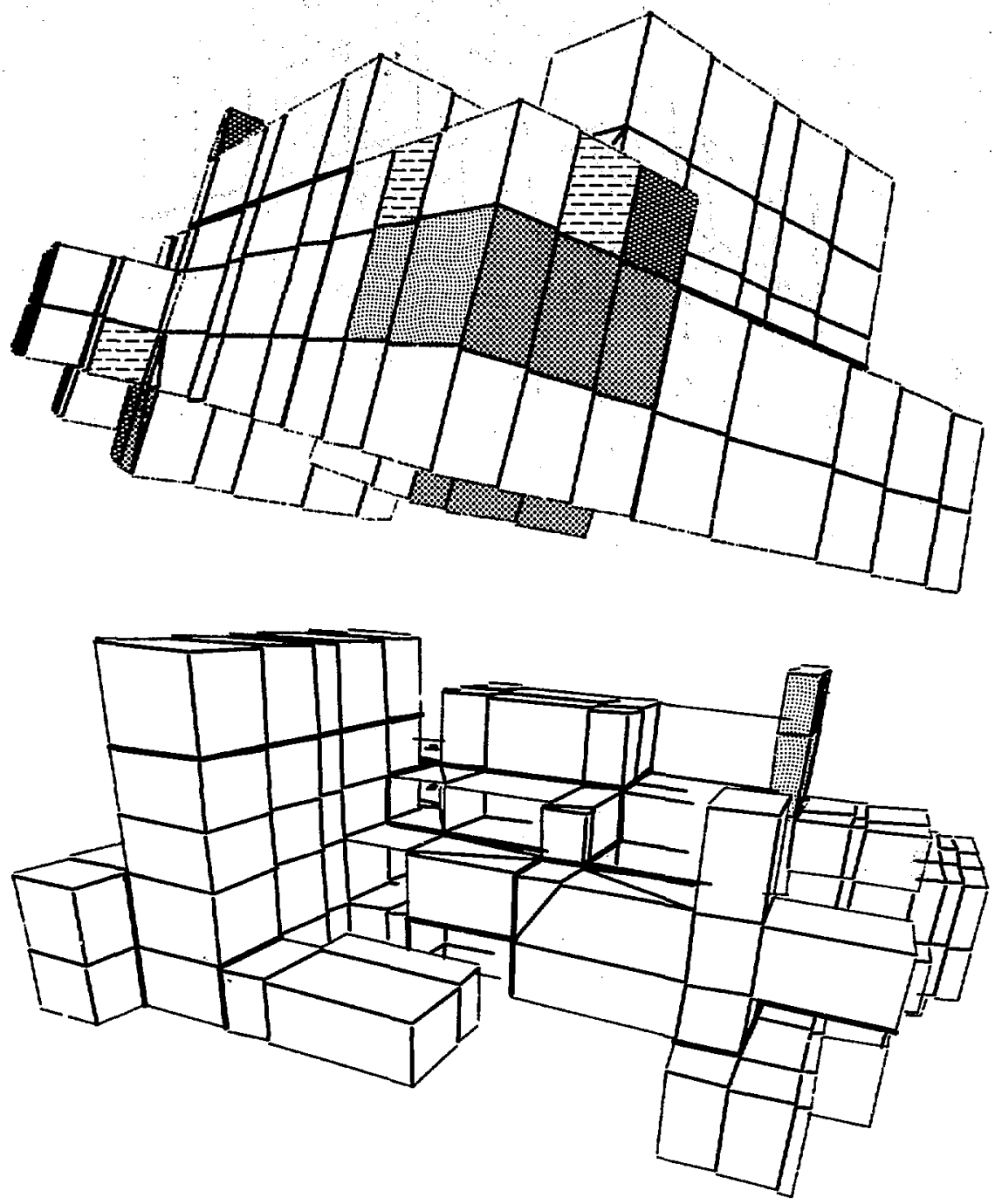

Onset of failure $0.03-0.08 \mathrm{~g}$

Onset of failure $00.08-0.12 \mathrm{~g}$

Onset of failure $00.12-0.16 \mathrm{~g}$

Onset of failure $0.16-0.20 \mathrm{~g}$

F1g. 18. Case 1 onset of shear wall fallure. 

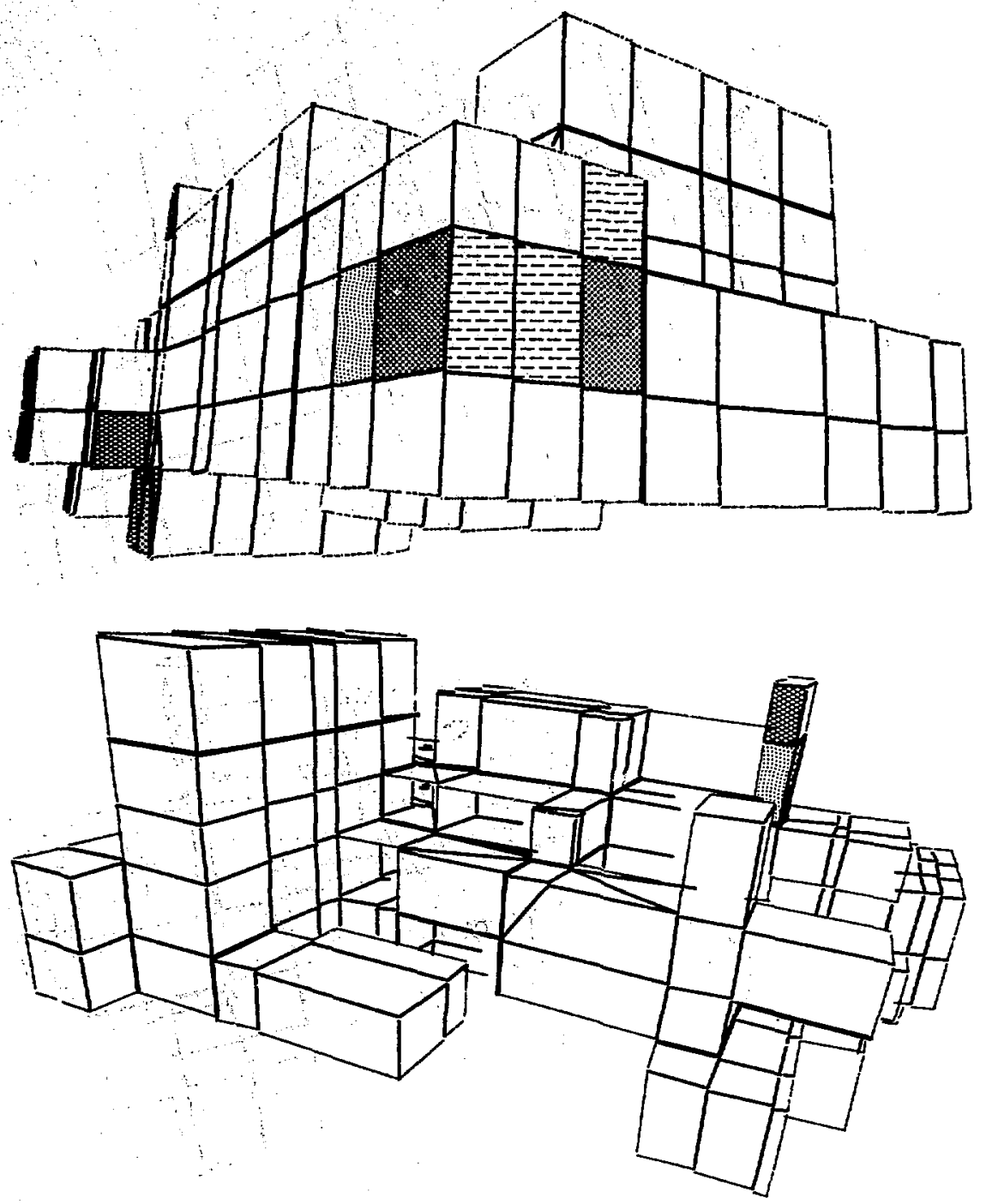

Onset of failure $0.0 .03-0.08 \mathrm{~g}$ Onset of fajlure $0.0 .08-0.12 \mathrm{~g}$ Onset of failure $00.12-0.169$ Onset of fallure $0.16-0.20 \mathrm{~g}$

Fig. 19. Case 2 onset of ahear wall fallure. 

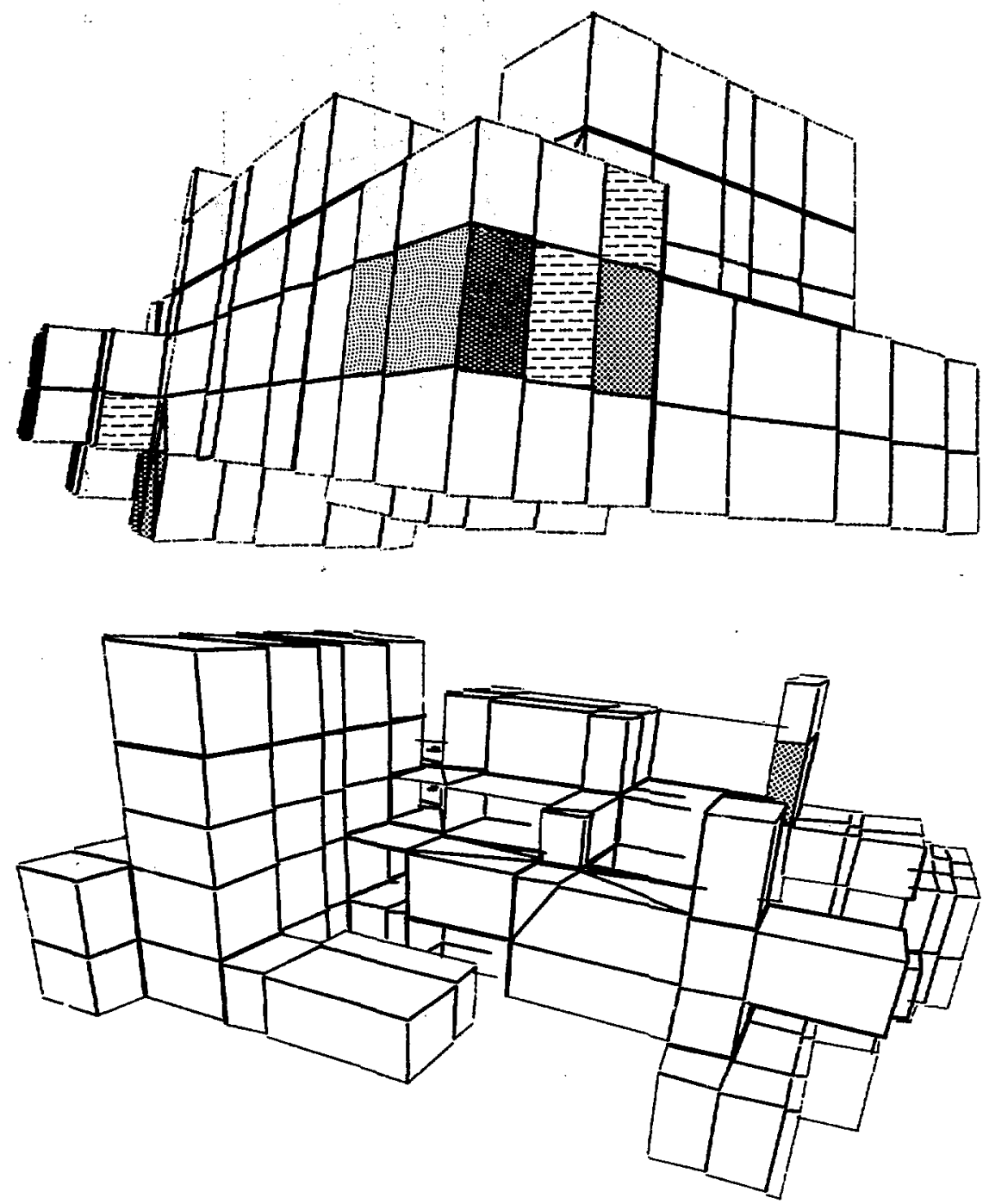

Onset of failure $0.03-0.08 \mathrm{~g}$

Onset of failure $0.08-0.12 \mathrm{~g}$

Onset of failure $0.12-0.16 \mathrm{~g}$

Onset of failure $0.16-0.20 \mathrm{~g}$

Fig. 20. Case 3 onset of shar wall failure. 

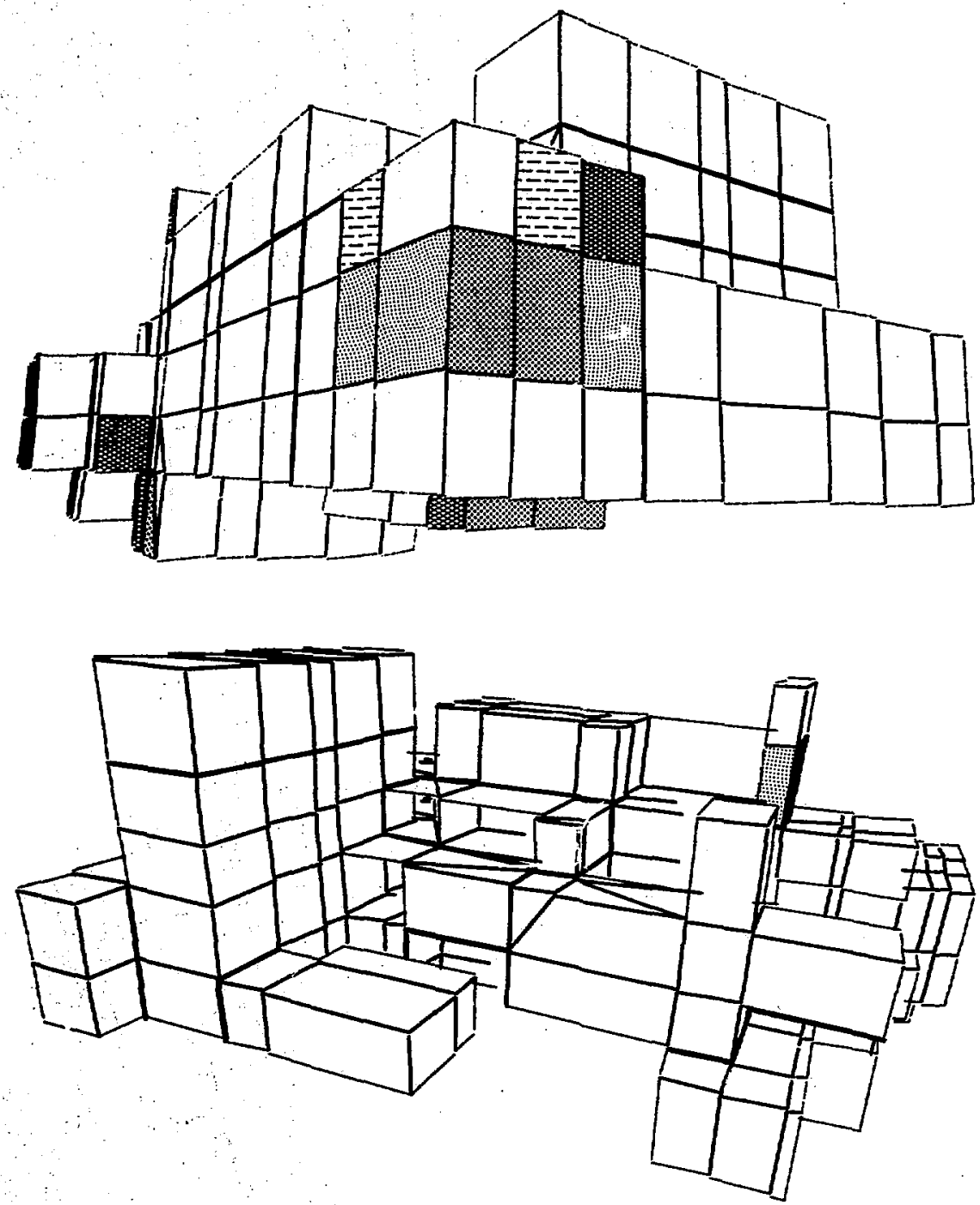

Onset of failure $0.0 .03-0.08 \mathrm{~g}$

20 Onset of failure $00.08-0.12 g$

Onset of failure $0.0 .12=0.16 \mathrm{~g}$

Onset of failure $0.16-0.20 \mathrm{~g}$

F1g. 21. Case 4 onset of shear wall fallure. 


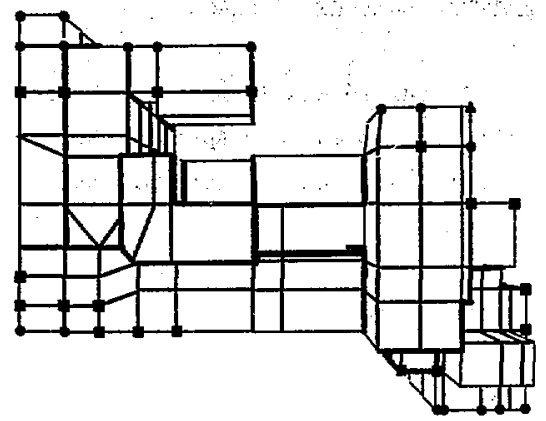

$\triangle$ Onset of failure $0.08-0.12 \mathrm{~g}$

- Onset of failure $0.12-0.16 \mathrm{~g}$

- Onset of fallure a $0.16-0.20 \mathrm{~g}$

Fig. 22. Case 1 pile tension fallure.

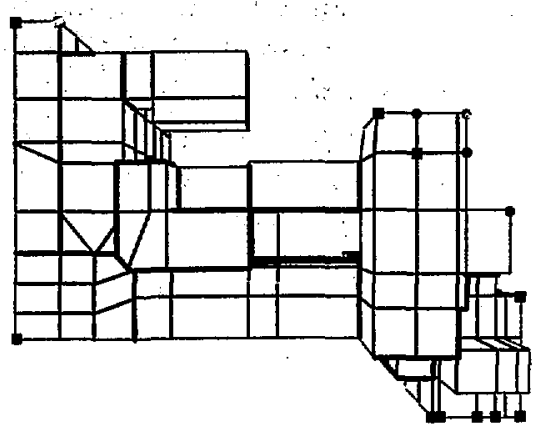

onset of failure $0.08-0.12 \mathrm{~g}$ - Onset of failure $0.12-0.16 \mathrm{~g}$ - Onset of failure $0.16 \cdot 0.20 \mathrm{~g}$

Fig. 24. Case 3 pile tension failure.

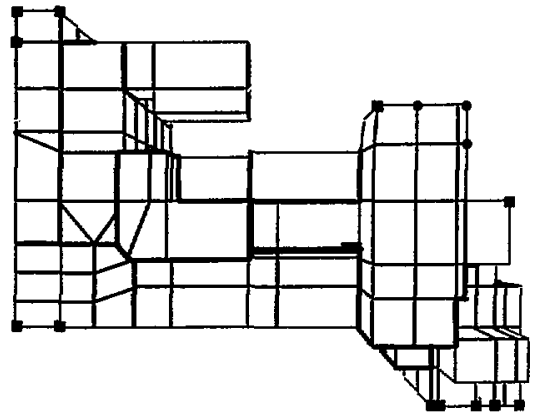

Onset of failure $0.08-0.12 \mathrm{~g}$

- Onset of failure $0.12-0.16 \mathrm{~g}$

- Onset of failure $0.16-0.20 \mathrm{~g}$

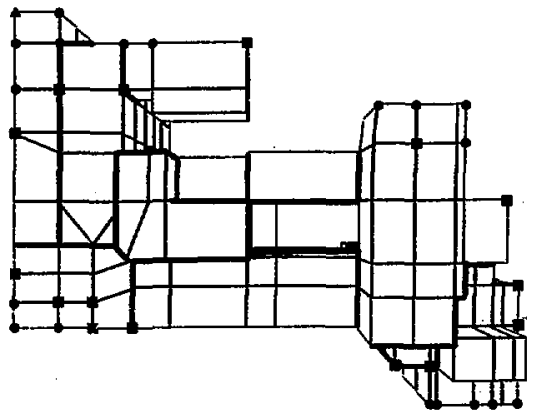

- Onset of failure $0.08-0.12 \mathrm{~g}$

- Onset of failure $0.12-0.16 \mathrm{~g}$

- Onset of failure $0.16-0.20 \mathrm{~g}$

Fig 23. Case 2 pile tension fallure. Fig. 25. Case 4 pile tension fallure. 
that experience a tensile loading with a peak earthquake ground accelera. tion of less than or equal to $0.2 \mathrm{~g}$. Wote that the modeled springs incorporate varying numbers of piles. The load cases that used the upper-bound soil apring atiffneases (cases one and four) resulted in the greatest number of pile spring fallures before a $0.2 \mathrm{~g}$ acceleration was reached. Ten percent of the piles falled in tension at $0.17 \mathrm{~g}$.

Tabie 8 tabulates, for each of the load cases, the pile springs that fall In tension and the g-level Intensity when tension first occurs. From these tables, it can be seen that pile tension first occurs at a $0.11 \mathrm{~g}$ peak ground acceleration (cases one and four). The faflure sequences that result when a single pile spring falls is difficult, if not impossible, to predict. Figures 22 through 25 Indcate, however, that several pile springs in concentrated areas Indcate tensile loads. At these areas, other related structural damage is expected.

\section{LATERAL FAILURE OF PILES}

Figurea 26 and 27 show the location of modeled pile epringe that exceed their maximum lateral load capacity at a peak ground acceleration $\leq 0.2 \mathrm{~g}$. The load cases where the minimum soll spring values were used (cases two and three) were the only cases where lateral pile fallure occurred.

Table 9 tabulates for each of the load cases the pile springs that exceed their lateral capactty and the g-level when these values were exceeded. From these tables it can be seen that the inttial pile spring exceeded the allowable value for case two at $0.05 \mathrm{~g}$. Tine initial failure for case three occurred at $0.07 \mathrm{~g}$. Ten percent of the piles failed due to lateral load at $0.11 \mathrm{~g}$.

PMC TO GPC CONNECTION

Our analysis of the PMC to GPC connection Indicates an adequate margin of safety. 
Table 8. Pile tension failure.

CASE 1

\begin{tabular}{|c|c|c|c|c|}
\hline $\begin{array}{l}\text { Foundation } \\
\text { node number }\end{array}$ & $\begin{array}{c}\text { P1le element } \\
\text { number }\end{array}$ & $\begin{array}{c}\text { Number of } \\
\text { piles }\end{array}$ & $\begin{array}{l}\text { Total } \\
\text { plles }\end{array}$ & $\begin{array}{l}\text { "g" } \\
\text { level }\end{array}$ \\
\hline $\begin{array}{r}352 \\
217 \\
220 \\
339 \\
297 \\
354 \\
296 \\
250 \\
358 \\
223 \\
226 \\
65 \\
355 \\
61 \\
89 \\
103 \\
121 \\
139 \\
57 \\
363 \\
45 \\
360\end{array}$ & $\begin{array}{r}204 \\
104 \\
107 \\
200 \\
160 \\
207 \\
157 \\
137 \\
213 \\
110 \\
113 \\
47 \\
210 \\
44 \\
62 \\
65 \\
72 \\
76 \\
41 \\
222 \\
32 \\
216\end{array}$ & $\begin{array}{l}1 \\
1 \\
1 \\
1 \\
4 \\
3 \\
3 \\
4 \\
1 \\
4 \\
2 \\
2 \\
2 \\
2 \\
1 \\
1 \\
1 \\
2 \\
3 \\
1 \\
2 \\
8\end{array}$ & $\begin{array}{r}1 \\
2 \\
3 \\
4 \\
8 \\
11 \\
14 \\
18 \\
19 \\
23 \\
25 \\
27 \\
29 \\
31 \\
32 \\
33 \\
34 \\
36 \\
39 \\
40 \\
42 \\
50\end{array}$ & $\begin{array}{l}0.111 \\
0.121 \\
0.123 \\
0.124 \\
0.128 \\
0.130 \\
0.135 \\
0.138 \\
0.140 \\
0.144 \\
0.146 \\
0.147 \\
0.147 \\
0.150 \\
0.151 \\
0.153 \\
0.156 \\
0.157 \\
0.160 \\
0.162 \\
0.167 \\
0.168\end{array}$ \\
\hline $\begin{array}{r}53 \\
68 \\
344 \\
41 \\
49 \\
299 \\
74 \\
232 \\
257\end{array}$ & $\begin{array}{r}38 \\
50 \\
201 \\
29 \\
35 \\
166 \\
56 \\
119 \\
140\end{array}$ & $\begin{array}{l}3 \\
2 \\
1 \\
3 \\
7 \\
3 \\
1 \\
2 \\
8\end{array}$ & $\begin{array}{l}53 \\
55 \\
56 \\
59 \\
66 \\
69 \\
70 \\
72 \\
80\end{array}$ & $\begin{array}{l}0.170 \\
0.173 \\
0.180 \\
0.181 \\
0.183 \\
0.183 \\
0.188 \\
0.189 \\
0.189\end{array}$ \\
\hline $\begin{array}{r}29 \\
298\end{array}$ & $\begin{array}{r}20 \\
163\end{array}$ & $\begin{array}{l}3 \\
5\end{array}$ & $\begin{array}{l}83 \\
88\end{array}$ & $\begin{array}{l}0.190 \\
0.190\end{array}$ \\
\hline $\begin{array}{r}37 \\
229 \\
71 \\
142 \\
207\end{array}$ & $\begin{array}{r}26 \\
116 \\
53 \\
79 \\
100\end{array}$ & $\begin{array}{l}1 \\
9 \\
4 \\
3 \\
9\end{array}$ & $\begin{array}{r}89 \\
98 \\
103 \\
106 \\
115\end{array}$ & $\begin{array}{l}0.192 \\
0.192 \\
0.193 \\
0.194 \\
0.195\end{array}$ \\
\hline $\begin{array}{l}157 \\
364\end{array}$ & $\begin{array}{r}82 \\
225\end{array}$ & $\begin{array}{l}1 \\
4\end{array}$ & $\begin{array}{l}116 \\
120\end{array}$ & $\begin{array}{l}0.197 \\
0.198\end{array}$ \\
\hline
\end{tabular}


Table 8. (Cont).

CASE 2

$\begin{array}{rrrrr}352 & 204 & 1 & 1 & 0.129 \\ 354 & 207 & 3 & 4 & 0.155 \\ 358 & 213 & 1 & 5 & 0.159 \\ 220 & 107 & 1 & 6 & 0.161 \\ 363 & 222 & 1 & 7 & 0.165 \\ 339 & 200 & 4 & 11 & 0.168 \\ 65 & 47 & 2 & 13 & 0.170 \\ 217 & 104 & 1 & 14 & 0.172 \\ 89 & 62 & 1 & 15 & 0.175 \\ 61 & 44 & 2 & 17 & 0.178 \\ 103 & 65 & 1 & 18 & 0.178 \\ 355 & 210 & 2 & 20 & 0.180 \\ 121 & 72 & 1 & 21 & 0.181 \\ 139 & 76 & 2 & 23 & 0.181 \\ 226 & 113 & 2 & 25 & 0.189 \\ 57 & 41 & 3 & 28 & 0.199^{a}\end{array}$

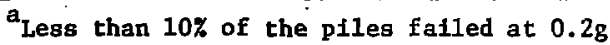

CASE 3

\begin{tabular}{|c|c|c|c|c|}
\hline $\begin{array}{l}\text { Foundation } \\
\text { node number }\end{array}$ & $\begin{array}{l}\text { Pile element } \\
\text { number }\end{array}$ & $\begin{array}{l}\text { Number of } \\
\text { piles }\end{array}$ & $\begin{array}{l}\text { Total } \\
\text { piles }\end{array}$ & $\begin{array}{l}\text { "g" } \\
\text { level }\end{array}$ \\
\hline $\begin{array}{r}352 \\
339 \\
358 \\
354 \\
363 \\
65 \\
220 \\
89 \\
355 \\
103 \\
217 \\
74 \\
344 \\
68 \\
61 \\
121 \\
360 \\
139\end{array}$ & $\begin{array}{r}204 \\
200 \\
213 \\
207 \\
222 \\
47 \\
107 \\
62 \\
210 \\
65 \\
104 \\
56 \\
201 \\
50 \\
44 \\
72 \\
216 \\
76\end{array}$ & $\begin{array}{l}1 \\
1 \\
1 \\
3 \\
1 \\
2 \\
1 \\
1 \\
2 \\
1 \\
1 \\
1 \\
1 \\
2 \\
2 \\
1 \\
8 \\
2\end{array}$ & $\begin{array}{r}1 \\
2 \\
3 \\
6 \\
7 \\
9 \\
10 \\
11 \\
13 \\
14 \\
15 \\
16 \\
17 \\
19 \\
21 \\
22 \\
30 \\
32\end{array}$ & $\begin{array}{l}0.127 \\
0.142 \\
0.154 \\
0.156 \\
0.159 \\
0.170 \\
0.178 \\
0.180 \\
0.185 \\
0.186 \\
0.186 \\
0.188 \\
0.189 \\
0.193 \\
0.195 \\
0.197 \\
0.197 \\
0.199^{a}\end{array}$ \\
\hline
\end{tabular}

${ }^{a}$ Less than $10 \%$ of the piles failed at $0.2 \mathrm{~g}$ 
Table 8. (Cont.).

CASE 4

\begin{tabular}{|c|c|c|c|c|}
\hline $\begin{array}{r}\text { Foundation } \\
\text { node number }\end{array}$ & $\begin{array}{c}\text { P1le element } \\
\text { number }\end{array}$ & $\begin{array}{c}\text { Number of } \\
\text { plles }\end{array}$ & $\begin{array}{l}\text { Total } \\
\text { piles }\end{array}$ & $\begin{array}{c}\text { "g" } \\
\text { level }\end{array}$ \\
\hline $\begin{array}{r}217 \\
352 \\
226 \\
65 \\
89 \\
223 \\
354 \\
103 \\
61 \\
121 \\
139 \\
339 \\
250 \\
358 \\
296 \\
355 \\
57 \\
45 \\
232 \\
363 \\
297 \\
68 \\
53 \\
41\end{array}$ & $\begin{array}{r}104 \\
204 \\
113 \\
47 \\
62 \\
110 \\
207 \\
65 \\
44 \\
72 \\
76 \\
200 \\
137 \\
213 \\
157 \\
210 \\
41 \\
32 \\
119 \\
222 \\
160 \\
50 \\
38 \\
29\end{array}$ & $\begin{array}{l}1 \\
1 \\
2 \\
2 \\
1 \\
4 \\
3 \\
1 \\
2 \\
1 \\
2 \\
1 \\
4 \\
1 \\
3 \\
2 \\
3 \\
2 \\
2 \\
1 \\
4 \\
2 \\
3 \\
3\end{array}$ & $\begin{array}{r}2 \\
3 \\
5 \\
7 \\
8 \\
12 \\
15 \\
16 \\
18 \\
19 \\
21 \\
22 \\
26 \\
27 \\
30 \\
32 \\
35 \\
37 \\
39 \\
40 \\
44 \\
46 \\
49 \\
52\end{array}$ & $\begin{array}{l}0.118 \\
0.119 \\
0.128 \\
0.133 \\
0.137 \\
0.138 \\
0.138 \\
0.139 \\
0.141 \\
0.142 \\
0.143 \\
0.145 \\
0.146 \\
0.148 \\
0.151 \\
0.153 \\
0.156 \\
0.158 \\
0.160 \\
0.161 \\
0.164 \\
0.166 \\
0.169 \\
0.178\end{array}$ \\
\hline $\begin{array}{r}220 \\
29 \\
360 \\
49\end{array}$ & $\begin{array}{r}116 \\
20 \\
216 \\
35\end{array}$ & $\begin{array}{l}9 \\
3 \\
8 \\
7\end{array}$ & $\begin{array}{l}61 \\
64 \\
72 \\
79\end{array}$ & $\begin{array}{l}0.178 \\
0.179 \\
0.181 \\
0.186\end{array}$ \\
\hline $\begin{array}{r}142 \\
157 \\
37 \\
238 \\
74 \\
71 \\
257\end{array}$ & $\begin{array}{r}79 \\
82 \\
26 \\
125 \\
56 \\
53 \\
140\end{array}$ & $\begin{array}{l}3 \\
1 \\
1 \\
3 \\
1 \\
4 \\
8\end{array}$ & $\begin{array}{r}82 \\
83 \\
84 \\
87 \\
88 \\
92 \\
100\end{array}$ & $\begin{array}{l}0.188 \\
0.193 \\
0.194 \\
0.194 \\
0.195 \\
0.197 \\
0.199\end{array}$ \\
\hline
\end{tabular}




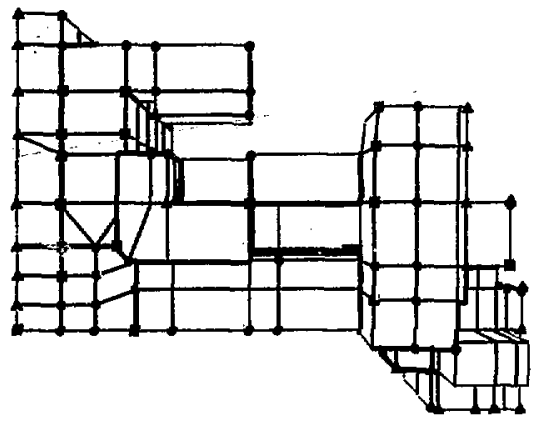

- Onset of failure $00.05-0.08 \mathrm{~g}$

- Onset of failure a $0.08-0.12 \mathrm{~g}$

- Onset of failure a $0.12-0.16 \mathrm{~g}$

- Onset of failure $0.16-0.20 \mathrm{~g}$

Fig. 26. Case 2 lateral pile fallure.

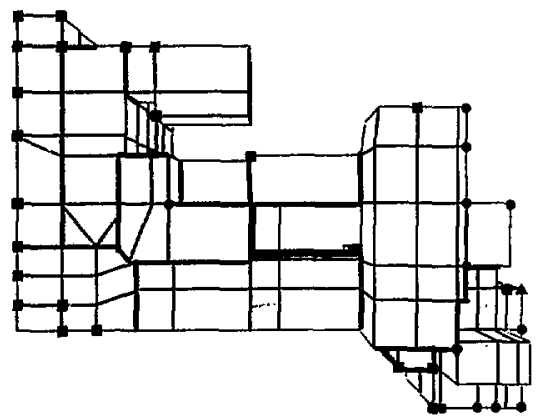

- Onset of fajlure $0.05-0.08 \mathrm{~g}$

- Onset of failure $0.08-0.12 \mathrm{~g}$

- Onset of faifure $0.12-0.16 \mathrm{~g}$

- Onset of failure o $0.16-0.20 \mathrm{~g}$

Fig. 27. Case 3 lateral pile failure. 
Table 9. Lateral fallure of piles

CASE 3

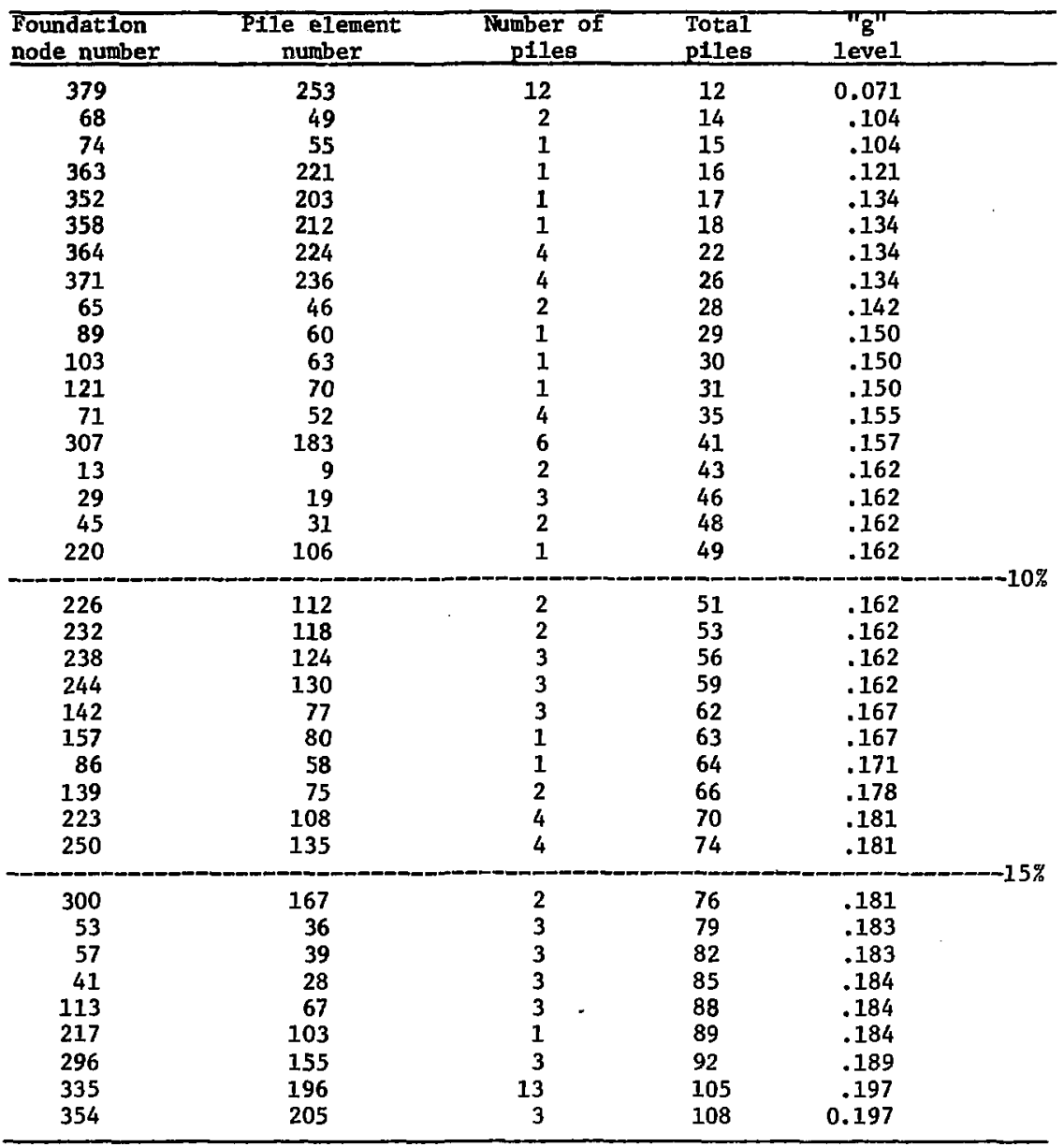


Table 9; (Cont.).

CASE 2

\begin{tabular}{|c|c|c|c|c|}
\hline $\begin{array}{l}\text { Foundation } \\
\text { node number }\end{array}$ & $\begin{array}{c}\text { Pile element } \\
\text { number }\end{array}$ & $\begin{array}{l}\text { Number of } \\
\text { piles }\end{array}$ & $\begin{array}{l}\text { Total } \\
\text { ptles }\end{array}$ & $\begin{array}{c}\text { "g" } \\
\text { level }\end{array}$ \\
\hline $\begin{array}{r}379 \\
68 \\
74 \\
363 \\
352 \\
358 \\
364 \\
371 \\
307 \\
65 \\
89 \\
103 \\
121 \\
142 \\
157 \\
13 \\
29 \\
45 \\
71\end{array}$ & $\begin{array}{r}253 \\
49 \\
55 \\
221 \\
203 \\
212 \\
224 \\
236 \\
183 \\
46 \\
60 \\
63 \\
70 \\
77 \\
80 \\
9 \\
19 \\
31 \\
52\end{array}$ & $\begin{array}{r}12 \\
2 \\
1 \\
1 \\
1 \\
1 \\
4 \\
4 \\
6 \\
2 \\
1 \\
1 \\
1 \\
3 \\
1 \\
2 \\
3 \\
2 \\
4\end{array}$ & $\begin{array}{l}12 \\
14 \\
15 \\
16 \\
17 \\
18 \\
22 \\
26 \\
32 \\
34 \\
35 \\
36 \\
37 \\
40 \\
41 \\
43 \\
46 \\
48 \\
52\end{array}$ & $\begin{array}{r}0.050 \\
.067 \\
.067 \\
.077 \\
.084 \\
.084 \\
.084 \\
.084 \\
.098 \\
.099 \\
.100 \\
.100 \\
.100 \\
.110 \\
.110 \\
.111 \\
.111 \\
.111 \\
.111\end{array}$ \\
\hline $\begin{array}{r}220 \\
226 \\
232 \\
238 \\
244 \\
300 \\
53 \\
57 \\
139 \\
187\end{array}$ & $\begin{array}{r}106 \\
112 \\
118 \\
124 \\
130 \\
167 \\
36 \\
39 \\
75 \\
89\end{array}$ & $\begin{array}{r}1 \\
2 \\
2 \\
3 \\
3 \\
2 \\
3 \\
3 \\
2 \\
12\end{array}$ & $\begin{array}{l}53 \\
55 \\
57 \\
60 \\
63 \\
65 \\
68 \\
71 \\
73 \\
85\end{array}$ & $\begin{array}{l}.111 \\
.111 \\
.111 \\
.111 \\
.111 \\
.119 \\
.121 \\
.121 \\
.122 \\
.123\end{array}$ \\
\hline $\begin{array}{r}193 \\
41 \\
217 \\
86 \\
223\end{array}$ & $\begin{array}{r}92 \\
28 \\
103 \\
58 \\
108\end{array}$ & $\begin{array}{r}12 \\
3 \\
1 \\
1 \\
4\end{array}$ & $\begin{array}{r}97 \\
100 \\
101 \\
102 \\
106\end{array}$ & $\begin{array}{r}.123 \\
.124 \\
.124 \\
.126 \\
0.126\end{array}$ \\
\hline
\end{tabular}


Table 9. (Cont.).

$\begin{array}{rrrrr}250 & 135 & 4 & 110 & 0.126 \\ 335 & 196 & 13 & 123 & .129 \\ 113 & 66 & 3 & 126 & .130 \\ 354 & 205 & 3 & 129 & .130 \\ 197 & 95 & 13 & 142 & .131 \\ 297 & 159 & 4 & 146 & .132 \\ 299 & 165 & 3 & 149 & .132 \\ 37 & 25 & 1 & 150 & 0.133\end{array}$

\section{Conclusions}

Two types of failure were Ident1fled in our analysis of this facility: 1) shear wall failure and 2) foundation failure.

Listed below are estimates of the onset of fallure and their locations. These results are presented to the Nuclear Regulatory Commission to assist them in evaluating the radiological consequences of these fallures. We have tried to include our intultion Into the structural consequences of these failure estimates.

SHEAR WALL FAILURE

Parts of thes nC start to fail at $0.07 \mathrm{~g}$. $\mathrm{T}$ :.s portion of the building is of concrete block construction and could experience enough dawage to collapse.

- One wall of the CPC begins to fall at $0.15 \mathrm{~g}$. $(0.08 \mathrm{~g}$ if we use the reduced allowable shear stress suggested by DRAVO). Th1s is an above ground structure and, thus, may cause a breach in confinement.

Parts of the LWC fail starting at $0.09 \mathrm{~g}$. These regions are below grade; thus, any liquid release would probably seep Into the soll. Th1s is a lower bound because of the way our model treats interconnections. We feel a more realistic value for this cell 1 s the average value of $0.17 \mathrm{~g}$.

- Portlons of GPC begin to fail at $0.09 \mathrm{~g}$. Th1s cell is also located below grade.

- Concrete block structures on top of the CPC begin to fall at $0.03 \mathrm{~g}$.

Those shear wall elements exceeding ultimate values may experience 
progressive cracking faflure dependIng on the number of peak load cycles. This may result in signiflcant breaches in confinement walls. The importance relative to confinement of - particular element is not known; however, the fallure of secondary elements such as shafts, bhielding doors, or control rooms, could affect the abijity, to monitor and control the plant during and after a seismic event.

It appears that the damage level experfenced by the reinforced concrete processing portions of the structure at the onset of fallure would not cause them to "fall down" under a $0.2 \mathrm{~g}$ earthquake. However, the progressive fallure nature of concrete subjected to cyclic loading could ultimately result in the bulldIng's demise, Because of the small ratio of reinforcement in this buildIng, a significant reserve capacity or ductility is not avallable to dissipate the energy imparted by a longduration $0.2 \mathrm{~g}$ earthquake.

The offlce portions: of the buildIng have not been included in this analysis. However; as evidenced by the performance of other concrete block portions of the building, they w111 moat 11kely experience heavy damage, Including posstble collapse. Th1s probably w111 not cause a $10 s 8$ of confinement but could result in $108 s$ of life for its occupants.

\section{FOUNDATION FAILURES}

Our analyeis indiceted lateral pile failure to begin at $0.11 \mathrm{~g}$ while pile tension failure begins at $0.17 \mathrm{~g}$. The effects of these pile failures are also not known. However, this might Intiate a progressive fallure which could undesirably redistribute forces to critical areas of the structure.

MODIFICATIONS TO IMPROVE SEISMTC RESISTAYCE

Extensive analyses beyond the scope of this project would be needed to recommend modifications for strengthening the existing faclity. Except for some accesstble shear walls, this structure would be difficult to upgrade for selsmic registance.

If upgrading were undertaken, it should also provide adequate protection agalnst other natural phenomena such as floods, extreme winds, and tornadoes.

\section{Areas for Further Investigation}

Possible future refinement of this analygis might be productive in the following areas:
Definttion of selsmic loading. Model refinement. Anàlysis reflnement. 


\section{DEHIXITION OF SEISAIC LOADING}

Invertigations could be undertaken to develop site-specific spectra at various ground acceleration levels. These Investigations are both time consuring and expensive but could refine the seiamic input.

MODEL REFINEMENT

Review of our results Indicates the structural response is strongly. Influenced by the stiffness coefficlents of the embedded structures. The range in values we used varfed by one order of magnitude. To reduce their range, more time could be spent reviewing the literature and comparing available methods for determining these stiffness coeffictents.

Refined zoning (smaller elements to model shear walls) would also improve the accuracy of the calculated stresses. This may be currently posstble with substructuring techniques o in the near future with larger winputers and more efficient computational tools.

The model could also attempt to account for some flexibility in the interconnections between varlous cells. An upper bound estimate on the period could be obtained by allowing no Interconnections between some cells. The model could be further refined by including linear or. nonlinear springs between varlous ce11s to model Interconnect Ions. Honlinear springs that become tnfinttely stiff In compression and that model Irlctional reslotance in tension could Improve est tmates of fallure.

\section{REFINE ANALYSIS}

With a refined model, a serles of time-history analyses could be coniucted to Identify better the onset of fallure and to study battering between adjacent structures. This could be extended further to study fallure progression by conducting a serles of elastic analyses where falled elements could be removed at appropriate times. Upon removal of falled elements, the g-level could be increased and the structure stiffness recalculated. By currently avallable methods, this would be an expensive and labortous procedure.

Other refinements in analysis that could be conducted by current techniques include: 1) combining multtdirectional input by the SRSS procedure, 2) using the techniques of Regulatory Guide 1.92 for combining closely spaced modes, and 3) incorporating nonproportional damping to allow different damping values to be used for the structure and the foundation. However, we feel these effects are of secondary importance and, In general, we chose a conservative approach. 


\section{Definition of Seismic Related Terms}

THE DYNAMIC PROBLEM

In describing the selsmic analysis of the NFS Fac1lity, we introduced terms which may require clarification. We constructed the mathematical model using shear walls, floor diaphragms, and uncoupled linear springs. A dynamic analysis was conducted to determine the modes of the structure including the mode shapes and periods. The loading was represented by a response spectrum for a specified damping value where the free-field ground spectrum was defined by the Regulatory Guide 1.60 spectrum. After applying the load to the structural model, the responses from each mode are combined by the SRSS procedure.

\section{SHEAR WALIS}

A building can resist horlzontal forces by one or a combination of two princlpal structural components: frames of concrete or steel, or reinforced concrete shear walls. Shear walls are deep, relatively thin, vertically cantilevered beams. The normal assumption for bullding analysis is that they resist horizontal foxces entirely by in-plane shear. That is, normal-to-the-plane bending does not contribute significantly to lateral resistance.

\section{FLOOR DIAPHRAGMS}

The inertial forces induced in vartous portions of the bullding during an earthquake must be transmitted to the lateral-force resistIng system, in this case, the shear wa11s. Tinese forces are transmitted by the floors (and roof) via diaphragm action. A diaphragm is a rigld horlzontal two-dimensional element that transmits load by In-plane action only.

JNCOUPLED LINEAR SPRINGS

The flexibility of the foundation was modeled by uncoupled linear springs. Each of these springs is an element in which its resistance is proportional to its axial extension only. They are uncoupled in that displacements along other axes or rotations do not affect their response.

MODE, MODE SHAPE, AND PERIOD

Every structural system has associated.with it the attribute of normal modes of vibration, which are a function of its mass and stiffness distribution. A system has exactly the same number of normal modes as degrees of freedom. Associated with each mode is a natural perlod and a 
characteristic shape. The distinguishing feature of a normal mode 18 that the system could, under certain circunstances, vibrate freely in that mode alone. During this free vibration, the ratio of the diaplacements of any two masses is constant with time. These ratios define the characteristic mode shape. The period of a mode is the time it takes for one complete oscillation during free vibration of that mode. The frequency of a mote is the number of oscillations per unit of a time (the reciprocal of pertod).

\section{SINGLE-DEGREE-OF-FREEDOM SYSTEM (SDOF)}

The dynamic response of a system subjected to a specifled base motion may be estimated by assuming that its mass, stiffness, and damping properties are concentrated into single physical elements, This model is called a single-degree-of-freedom system (FIg. 28). Once the system has been modeled, a response spectrum can be used directly as input motion to determine the naximum response.

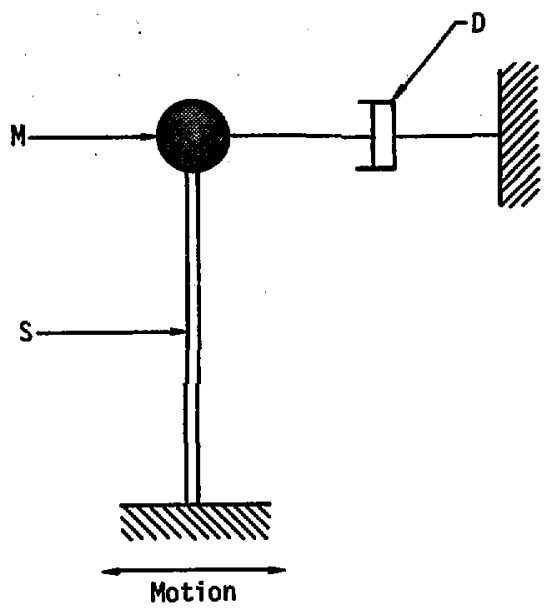

FIg. 28. Single-degree-of-freedom system. Mass concentrated at single point $M$. Damping and stiffness characteristics concentrated In single elements $D$ and $S$, respectively.

coordinate; that 1s, a multipledegree-of-freedom system is required to capture the motion. Frequently, however, only the first few modes are needed to adequately describe the structure's response.

\section{DAMPING VALUE}

MULTIPLE-DEGREE-OE-FREEDOM SYSTEM (MDOF) :

The response of a structure,

Often, dynamic response of a real system, or component usually has structure cannot be described with energy dissipation assoclated with single-degree-of-freedom systems. True behavior can only be degcribed it. These energy losses may be caused by Internal energy dissipation within in terms of more than one displacement the material or support, or foint 
11ppage, and they are normally accounted for by means of a damping value.

Design damping values typically range fron 0.5 to $10 \%$ of critical damping. Damping can have a significant "effect on the dynamic response of the structure.

In this study, velocity-dependent damping was assumed, which is a standard modeling procedure in structural analysis.

\section{RESPONSE SPECTRUM}

A rasponse spectrum is represented schematically in Fig. 29. A serles of single-degree-of-freedom systems (cantilever pendulums) with varying fundamental frequencies are fixed to a moveable base. As the length of the pendulums increases, the fundamental frequency decreases. If the base is moved with a time-varytag motion and the motion of each pendulum is recorded, a curve cap be developed that plots the maximum response against the frequency of each pendulum. This curve is called the response spectrum for that particular input motion, and Is also shown in FIg. 29. The response motion can be displacement, velocity, or acceleration because all are related to frequency. It 1s posstble to generate spectra for both vertical and horfyontal base motiona.
FREE-FIELD GROUND-RESPONSE SPECTRUM

If the series of ofingle-degree-of-: freedom systems (penduiums) are assumed supported on the ground and are subjected to free-fleld ground motion resulting from an earthquake, then the response spectrum curve developed is called a groundmotion spectrum.

(a)
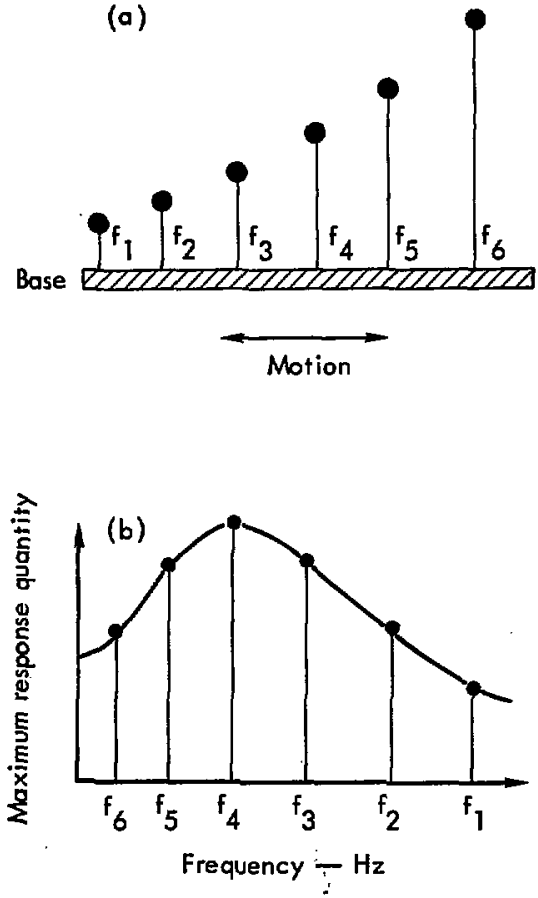

Fig. 29. Simulated cantilevered beams of varying response frequencies. (a) Pendulims of varying response frequency. (b). Plot of maximum response quantity for each singledegree-of-freedom system for particular input motion. 
The free-field ground motion is the surface motion Induced by an earthquake that has not been altered by the presence of a structure. Figure 30a shows an example of the acceleration ground-motion spectrum for the 1940 E1 Centro earthquake. FIgure $30 \mathrm{~b}$ shows the measured hor $1-$ zontal accelerogram record used as input to develop this spectrum.

Figure 31 shows the free-field grourd-motion spectra currently used to define seismic input for nuclear power reactors. 15 These smooth
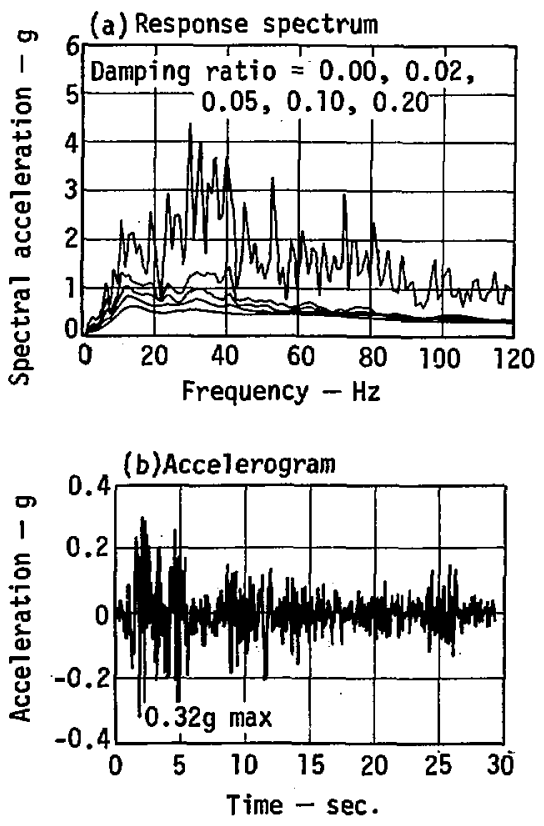

Fig. 30. 1940 E1 Centro earthquake. spectra are based on a statistical treatment of approximately 47 earthquake records. They are plotted on tripartite $\log$ paper for the conve;Ience of having maximim acceleration, velocity, and displacement values as a function of frequency on one plot. They are normalized to a maximum horizontal ground ac leration of $1.0 \mathrm{~g}$. Once the intensity of ground motion for a site is specified in terms of maximum horlzontal ground acceleration, both horizontal and vertical spectra can be defined simply by scaling.

SRSS

When analyzing a structure by the response-spectrum technique, one obtains the maximum response for each mode considered. Since these Individual modal maxima do not occur at the same time, a statistical procedure is used to combine these maxima. The procedure used is the square root of the sum-of-the-squares method (SRSS). For this method, the following procedure is used:

$$
\begin{aligned}
& v_{1}=\text { value for mode } 1 \\
& v_{S R S S}=\sqrt{v_{1}^{2}+v_{2}^{2}+\ldots+v_{N}^{2}} \\
&=\sqrt{\sum_{i=1}^{N} v_{1}^{2}}
\end{aligned}
$$




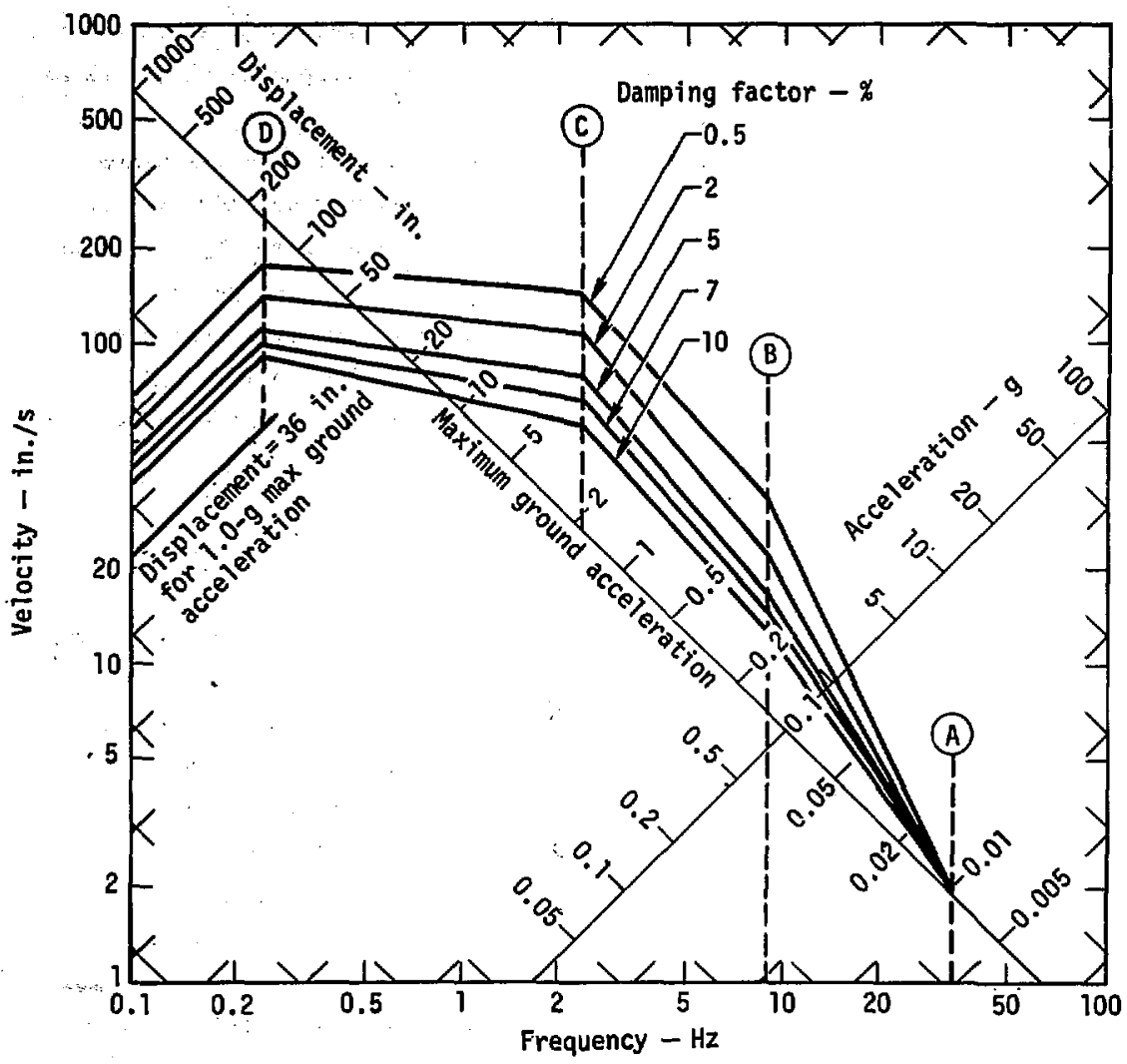

F1g. 3i. Horizontal design response spectra, scaled to $1-g$ horizontal ground acceleration (from Regulatory Guide 1.60). Example: for 5\% damping and $f=0.25 \mathrm{cps}, D=73.8 \mathrm{in.}, v=115.93 \mathrm{in.} / \mathrm{s}$, and $a=0.47 \mathrm{~g}$. 


\section{Acknowledgment}

The authors wish to acknowledge the assistance of Robert Bernero, Winston Burkhardt, A. Thomas Clark, and Ronald Clary of the U.s. Nuclear Regulatory Commission, Office of Nuclear Materlal Safety and Safeguards, Division of Fuel Cycle and Material Safety, for providing guidance and support throughout this study.
We also appreclate the time spent by Nuclear Fuel Services, Inc., and the Dravo Corporation. Their assistance and cooperation have been most helpful. Finally, we wish to thank Frank Tokarz for his advice and support throughout this project, and Shirley Calvert for typing the manuscripts and preparing the figures. 


\section{References}

1. Safety Analysis Report, NFS' Reproceseing Plant, West Valley, New York, Docket Number 50-201 (Nuclear Fucl Services, Inc., Rockville, MD, 1973).

2. NRC, LLL, LASL Meeting; Washington, D.C., private communication, August $24,1976$.

3. D. F. Arthur, R. G. Dong, R. C. Murray, T. A. Nelson, P. D. Smith and I. H. Wight, Evaluation of Methods for Seismic Analysis of Nuclear Fuel Reprocessing Plants and Fabrication Facilities, Lawrence Livermore Laboratory, Livermore, CA. Rept. UCRI-52159 (to be published).

4. F. J. Tokarz; R. C. Murray; D F. Arthur, W. W. Feng, L. H. Wight, M. Zaslawsky, Evaluation of Methods for Seismic Analysis of Muclear Fuel Reprocessing Plants, Part 1, Lawrence Livermore Laboratory, Livermore, CA Rept. UCRL-51802, Pt. 1 (February, 1975).

5. Naval Facilities Engineering Command, Soil Mechanice, Foundations, and Earth Structures, Department of the Navy, NAVFAC DM-7 (March, 1971-through Change 2-March, 1974).

6. W. V. Brewer, Lawrence Livermore Laboratory, Livermore, CA, Private communication (July, 1976). Included also in UCID-17453.

7. G. R. Johnson, P. Christiano, and H. I. Epstein, "Stiffness Coefficients for Embedded Footings," Journal of the Geotechnical Engineering Division, ASCE, Vo1. 101, No. GT8 Proc. Paper 11522 (August, 1975), and Electric Power and the Civil Engineer, ASCE Power DIvision Specialty Conference (August 1974) pp. 469-498.

8. R. A. Parmelee, R. J. Kudder, "SeIsmic Soil-Structure Interaction of Embedded Bulldings," Fifth World Conference on Earthquake Engineering, Preprint No. 24la (Rome, Italy, 1973.

9. R. A. Parmelee, and J. H. Wronkiewicz, "Dynamic Coefficlents for EvaluatIng the Seismic Response of Soll-Structure Interaction System," Fifth World Conference on Earthquake Engineering, Preprint No. 330 (Rome, Italy, 1973).

10. 1973 Uniform Building Code (International Confererce of Bullding Offictals Whittier, CA, 1973).

11. U.S. Nuclear Regulatory Comission, Regulatory Guide 1.92, Combination of Modes and Spatial Components in Seiamic Response Analysis (U.S. Government Printing office, Washington, D.C., February 1976. 
12. K. J. Bathe, E. L. Wilson, and F. E. Peterson, SAP IV - A Stmuctural Analyois Program for Static and Dynamic Response of Lineor Systems, Earthquake Engineering Research Center, University of California, Berkeley, CA, Rept. EERC $73-11$ (1973).

13. B. E. Brown, Stmictural Analysis Movie Postprocessor (SAMPP), Lawrence Livermore Laboratory, Livermore, CA Rept. UCID-30097, Rev. 1 (October 1975).

14. W. H. Collins, and D. F. Arthur, Private communications, Lawrence Livermore Laboratory, Livermore, CA (1976).

15. U.S. Nuclear Regulatory Commission, Regulatory Guide 1.60, Design Response Spectra for Seismic Design of Muclean Power Plants (U.s. Government PrintIng Office, Washington, D.C., December 1973).

16. U.S. Nuclear Regulatory Commission, ReguZatory Guide 1.61, Damping Values for Seismic Design of Nuclear Power Plants, (U.S. Government Printing office, Washington, D.C., October 1973).

17. E. Endebrock, Private communications, Los Alamos Scientific Laboratory (September 20, 1976).

18. Structural Analysis and Design of Nuclear Power Plant Facilities (Draft), Committee on Nuclear Structures and Materials of the Structiral Division, ASCE (1976).

19. A. E. Cardenas, et al., "Design Prov1sions for Shear Walls," Froceedings, American Concrete Institute, Vol. 70 (March 1973).

20. ACI Committee 318, Building Code Requirements for Reinfored Conerete ACI 318-71 (American Concrete Institute, Detroit, MI, 1971).

21. Selsmology Committee, Recommended Lateral Force Requirements and Conmentary, (Structural Englneers Association of California, San Francisco, CA, 1973).

22. Joint ASCE-ACI Task Committee 426, "The shear strength of Reinforced Corcrete Members," Joumal of the Structural Division, ASCE, Vol. 99, No. ST6, Proc. Paper 9791 (June 1973).

23. J. E. Amrhein, Reinforced Masonry Engineering Handbook (Masonry Institute of America, Los Angeles, CA, 1973), 2nd d.

24. Masonry Institute of America, Los Angeles, CA, and Western States Clay Products Association, San Francisco, CA, private communications (1975).

LRS/ck/vt/ff 